\title{
Positivism and the Notion of an Offense
}

\author{
Claire Finkelstein $\dagger$
}

Yet law-abiding scholars write

Law is neither wrong nor right.-W.H. Auden

While the United States Supreme Court has developed an elaborate constitutional jurisprudence of criminal procedure, it has articulated few constitutional doctrines of the substantive criminal law. The asymmetry between substance and procedure seems natural given the demise of Lochner and the minimalist stance towards due process outside the area of fundamental rights. This Article, however, argues that the "positivistic" approach to defining criminal offenses stands in some tension with other basic principles, both constitutional and moral. In particular, two important constitutional guarantees depend on the notion of an offense: the presumption of innocence and the ban on double jeopardy. Under the positivistic orthodoxy, the scope of these doctrines is left to state legislatures to determine. The presumption of innocence and the ban on double jeopardy thus suggest the need for a substantive conception of the notion of an offense. This Article attempts to provide a jurisprudential framework for developing such a conception. It proceeds from the idea that we have a presumption against the use of the criminal sanction, stemming from the commitment to a background right to liberty our constitutional jurisprudence contains. The use of the criminal sanction is justifted only if the infringement of liberty it imposes is sufficient to overcome that presumption. This requirement of justification in turn suggests boundaries on the notion of an offense: The deftnition of an offense must be constructed in a way that makes the infringement of liberty justified in light of the harm the prohibited conduct inflicts.

\section{Copyright (C) 2000 California Law Review, Inc.}

$\dagger \quad$ Acting Professor of Law, University of California, Berkeley, School of Law (Boalt Hall). The author wishes to thank Matt Adler, Larry Alexander, Ruth Gavison, Jim Gordley, Leo Katz, Robert Post, Connie Rosati, and Maimon Schwarzschild for helpful discussions on the topic of this article and for comments on various drafts. She is also grateful for the support of the University Center for Human Values (Princeton University), where this article was mostly written, as well as to Kim Kempton for her assistance with research. 


\section{INTRODUCTION}

Among the various questions to which criminal law theorists could devote their attention, one might expect "What is a crime?" to rank first and foremost. Surprisingly little effort, however, has been expended answering it. Moreover, there is little consensus even among those who have studied the matter closely. Some think of a crime as an immoral act, taking the view that all and only immoral acts ought to be punished.' Others adopt a more relativistic position, claiming that a crime is a community's emphatic denunciation of a type of conduct, and that the only legitimate basis for criminalization is social. ${ }^{2}$ Still others offer an economic rationale, mamtaining that a crime is a coercive transfer of resources from victim to perpetrator, which is inefficient because it bypasses an available voluntary market. ${ }^{3}$

Ironically, one answer academics do not normally advance is the answer the American legal system has nost consistently endorsed: A crime is whatever a legislature passes into law under the heading "criminal." Our legal system, in short, takes a predominantly positivistic approach to the notion of crime, meaning that there is no particular structure or content that legislation denominated "criminal" must have. As Henry Hart wrote a number of years ago, "If one were to judge from the notions apparently underlying many judicial opinions, and the overt language even of some of them ... a crime is anything which is called a crime, and a criminal penalty is simply the penalty provided for doing anything which has been given that nanie." 4 This suggests a gap between academic intuitions and judicial behavior about the nature of crime. Academics search for criteria to determine which activities are proper objects of prohibition, based on their adherence to norms that they believe ought to govern the use of the criminal sanction. Judicial oversight of criminal statutes, by contrast, proceeds as if no such norms were available. One explanation for this gap might be that academics who have offered a general account of crime have not for the most part attempted to translate their theories into concrete proposals for defining offenses. A theory of crime will remain judicially idle unless it can also provide a way of identifying constraimts on the kinds of criminal statutes legislatures may draft.

1. See Michael Moore, Placing Blame 637-67 (1997). H.L.A. Hart coined the expression "legal moralism" to refer to this position. H.L.A. HART, LAW, LiberTY, AND MORALITY 6 (1963); see also infra Part III (discussing Moore on legal moralism).

2. See H.L.A. HART, PUNishment AND ResPonsibility 6-8 (1967).

3. See Richard Posner, An Economic Theory of the Criminal Law, 85 Colum. L. REv. 1193 (1985) (presenting a theory of crime in terms of an intentional bypass of an available voluntary inarket).

4. Henry M. Hart, Jr., The Aims of the Criminal Law, 23 L. \& ConTEMP. ProBs. 401, 404 (1958) (citations omitted). 
The suggestion that the Court takes a positivistic stance towards the notion of an offense requires explanation. Historically, legal positivism has been contrasted with natural law theories. In this sense, nearly all contemporary legal doctrines are positivistic, in that they are self-avowedly conventional, not natural. ${ }^{5}$ We might also say, however, that a legal doctrine or concept is "positivistic" if it derives its content entirely from legislative pronouncement. It is substantive, or nonpositivistic, if it derives its content at least in part from deeper and inore fundamental principles. Where the notion of an offense is concerned, the nonpositivistic alternative is to treat the substantive provisions of the criminal law as resting on a set of constitutional values. The Supreme Court's approach to the notion of an offense is positivistic in this sense, then, because the Court has been unwilling to constitutionalize the basic doctrines of the criminal law.

The Court's commitınent to positivism has mamifested itself most obviously in its approach to strict liability crimes, where it has gone to some lengths to avoid having to pronounce the inclusion of a mental state requirement in offense definitions a matter of constitutional mandate. ${ }^{6}$ The closest the Court has come to constitutionalizing mens rea was its declaration that traditional common law crimes should be construed as requiring scienter where the legislature is silent as to intent. This principle, however, is a rule of construction, not a constitutional requirement. ${ }^{7}$ The Canadian Supreme Court, by contrast, has been less restrained. It has found strict liability crimes "not in accordance with the precepts of fundamental justice" guaranteed by the Canadian Charter of Rights and Freedoms. ${ }^{8}$ The positivistic stance towards offense defimition has also appeared in the Court's approach to the defenses of the criminal law. It is apparently a matter of constitutional indifference whether a state chooses to grant its citizens defenses such as provocation, ${ }^{9}$ self-defense, ${ }^{10}$ intoxication, ${ }^{11}$

5. Even Ronald Dworkin, who argues that principles of our moral and political philosophy should inform the interpretation of both constitutional and statutory provisions, does not attempt to claint that these background primciples are drawn from the natural order of the universe. He suggests instead that they are deep-seated commitments of our social practices, but that they nevertheless should occupy the kind of foundational position that precepts of natural law might once have occupied. See RONALD DWORKIN, LAW's EMPIRE, 78-85, 266-71 (1986). The only prominent contemporary legal theorist who endorses natural law theory wholeheartedly is John Finnis. See, e.g., JoHN FINNIS, Natural LaW AND Naturai Rights (1980).

6. See United States v. Dotterweich, 320 U.S. 277 (1943) (holding president of conipany criminally liable for drug shipment of which he was entirely ignorant); United States v. Balint, 258 U.S. 250, 252 (1922) (accepting strict liability statute designed for "social betterment" rather than punishment); see also Alan C. Michaels, Constitutional Innocence, 112 HARv. L. Rev. 828, 832 (1999) and sources cited therein.

7. See Morissette v. United States, 342 U.S. 246 (1952) (establishing a rule that common law crimes contain a mens rea requirenient if legislature silent on mental state).

8. Can. Const. (Constitution Act, 1982) pt. I (Canadian Charter of Rights and Freedoms), cl. $11, \S 7$.

9. See Patterson v. New York, 432 U.S. 197 (1977) (upholding New York law shifting burden to prove provocation to defendant). 
mistake of law, ${ }^{12}$ or even insanity. ${ }^{13}$ Similarly, the Constitution supposedly has little to say about the use of legal presumptions, ${ }^{14}$ despite the serious constitutional difficulties they appear to raise when used to prove the elements of a criminal offense. ${ }^{15}$

The Court's commitment to positivism about offense definition, however, has not been monolithic. One exception is the line of cases establishing restrictions on the way criminal offenses are drafted, stemming principally from the due process requirement that citizens be placed on notice of their potential subjection to criminal sanctions. ${ }^{16}$ Statutes have been routinely struck down for failing to identify the prohibited conduct with precision, or for casting the net of criminalization too broadly, thus subjecting individuals to criminal punishment for engaging in ordinary, protected activities. ${ }^{17}$ Another is the line of cases represented by Robinson $v$. California ${ }^{18} \mathrm{im}$ which the Court struck down legislation criminalizing a defendant's condition. There are even isolated cases, Lambert $v$.

10. See Martin v. Ohio, 480 U.S. 228 (1987) (upholding Ohio's burden-shifting provision with respect to self-defense on grounds that state has no obligation to provide defense of self-defense).

11. See Montana v. Egelhoff, 518 U.S. 37 (1996) (upholding state law rendering evidence of voluntary intoxication inadmissible).

12. See United States v. International Minerals \& Chemical Corp., 402 U.S. 558, 563 (1971). The Court has nevertheless eroded this principle around the edges by declaring a rule of statutory construction in favor of such a defense. See Liparota v. United States, 471 U.S. 419 (1985) (interpreting mens rea requirements with regard to mistake of law).

13. See Leland v. Oregon, 343 U.S. 790 (1952) (upholding state law shifting burden of proof on insanity defense).

14. See Ferry v. Ramsey, 277 U.S. 88 (1928) (holding use of presumptions a matter of legislative discretion).

15. The Court has however found the use of mandatory presumptions unconstitutional. See Ulster County Court v. Allen, 442 U.S. 140, 157 (1979) (finding mandatory presumptions troublesome because they affect both the strength and placement of the "no reasonable doubt" burden); Sandstrom v. Montana, 442 U.S. 510, 521-523 (1979) (rejecting mandatory presumptions on the grounds that they establish a conclusive inference). See generally Harold A. Ashford \& D. Michael Risinger, Presumptions, Assumptions, and Due Process in Criminal Cases: A Theoretical Overview, 79 YALE L.J. 165, 178 (1969) (arguing that burden of persuasion operating under pcrmissible inference is no different from any other burden of persuasion).

16. See Papachristou v. City of Jacksonville, 405 U.S. 156 (1972) (finding Jacksonville vagrancy ordinance void for vagueness on grounds that it fails to give persons of ordinary intelligence fair notice that contemplated conduct is forbidden and because it encourages arbitrary arrests and convictions).

17. The so-called "overbreadth" eases have mainly eoncerued First Amendment rights. See R.A.V. v. City of St. Paul, 505 U.S. 377 (1992) (striking down ordinance prohibiting cross burning as overbroad); Texas v. Johnson, 491 U.S. 397 (1989) (striking down law making it illegal to deface flag); Massachusetts v. Oakes, 491 U.S. 576, 584 (1989) ("Overbreadth is a judicially created doctrine designed to prevent chilling of protected expression."); Lewis v. City of New Orieans, 415 U.S. 130 (1974) (striking down statute on grounds that it is susceptible of application to speech protected by First Amendment); Gooding v. Wilson, 405 U.S. 518 (1972) (upholding decision of Fifth Circuit striking down statute eriminalizing using "'opprobrious words or abusive language" as vague and overbroad).

18. 370 U.S. 660 (1962) (striking down statute criminalizing status of being an addict). But see Powell v. Texas, 392 U.S. 514 (1968) (holding that punishment for public drunkenness is no violation of due process). 
Califormia $^{19}$ providing the best example, in which the Court has invalidated criminal legislation because of its discomfort with the use of strict liability, despite the official stance that criminalization in the absence of mens rea is constitutionally acceptable.

The largest area of substantive review, however, is the line of cases reviving the doctrine of substantive due process. The most significant of these are the cases vindicating a constitutional right to privacy. Here the Court has been unabashed in engaging in substantive review of criminal legislation to protect a nonenumerated right. Under this heading, the Court has refused to allow states to prohibit the use of birth control between married persons, ${ }^{20}$ the use of pornographic material in the privacy of one's home, ${ }^{21}$ the right of women to choose to terminate an unwanted pregnancy, ${ }^{22}$ the right of minors to seek an abortion without parental notice, ${ }^{23}$ and even the right of homosexuals to challenge legislation discriminating against them. ${ }^{24}$

This is not to deny the Court's persistent unease with its own intermittent willingness to police the boundaries of the substantive criminal law. As Charles Nesson has written, "each time the Court has ventured into substantive limitation theory it has quickly retreated." 25 Thus Robinson ${ }^{26}$

19. 355 U.S. 225 (1957) (finding ordinance requiring convicted felons to register with the police in Los Angeles within five days of arrival unconstitutional).

20. See Griswold v. Connecticut, 381 U.S. 479 (1965) (striking down Connecticut statute illegalizing use of birth control).

21. See, e.g., Stanley v. Georgia, 394 U.S. 557 (1969) (striking down Georgia statute making private possession of obscene matter a crime).

22. See Roe v. Wade, 410 U.S. 113 (1973) (holding that the right to privacy includes a woman's decision whether or not to terminate a pregnancy).

23. See Guste v. Jackson, 429 U.S. 399 (1977) (vacating an injunction against enforcement of a Louisiana statute forbidding the performance of an abortion on a minor without her parents' or husband's consent).

24. See Romer v. Evans, 517 U.S. 620 (1996) (striking down Amendment 2 of Colorado State Constitution on grounds that it denies gays and lesbians equal protection of the law). Granted, the official doctrine insists that the only reason there is federal judicial power to review criminalization decisions in this area for more than their rationality is that privacy is a recognized fundanental right. Like free speech, infringements on the right to privacy must be justified by a "compelling state interest." But this rationale has seemed to many somewhat disingenuous, for at least two reasons. First, the only real support for the idea of a fundamental constitutional right to privacy are the very cases striking down privacy-infringing legislation. See supra notes 20-22 and sources cited therein. Second, arguably the more natural way to understand the interests at stake in such cases is that they are aspects of a right to hberty. But since the demise of Lochner, official doctrine has rejected the idea that the Due Process Clause contains a general notion of hiberty with independent constitutional meaning, apart from the guarantees of the Bill of Rights and those "liberty" interests a state chooses to grant its citizens. Lochner v. New York, 198 U.S. 45 (1905).

25. Charles R. Nesson, Rationality, Presumptions, and Judicial Comment: A Response to Professor Allen, 94 HARv. L. REv. 1574, 1581 (1981) (citations omitted) (critiquing Ronald Allen's theory of burden-shifting devices).

26. 370 U.S. at 660 (holding required 90-day imprisonment based on the "status" of narcotic addict inflicted "cruel and unusual punishment" in violation of the Eighth Amendment). 
was followed by Powell, ${ }^{27}$ Furman $^{28}$ by Gregg, ${ }^{29}$ and Mullaney ${ }^{30}$ by Patterson. ${ }^{31}$ The same dynamic appears to be at work between Solem $^{32}$ and Harmelin, ${ }^{33}$ Grady $^{34}$ and Dixon, ${ }^{35}$ and even perhaps Lambert ${ }^{36}$ and later decisions like Park. ${ }^{37}$ But instead of concluding, as Nesson does, that the Court is permanently set against substantive limitation theory, one might see the history as attesting to a pull in the opposite direction. Our constitutional tradition displays both tendencies, and while the rejection of a constitutionalized criminal law enjoys strong support from the official demise of substantive due process, there are conflicting threads in our constitutional jurisprudence that inerit consideration.

This Article proposes a reexamination of the official rejection of substantive limitation theory. Others have recently issued the same plea on the grounds that the sharp distinction between substantive and procedural rules with regard to judicial oversight cannot be justified ${ }^{38}$ Still others argue that it should be unconstitutional to punish a person who is not blameworthy, and they accordingly propose that mens rea should be a constitutional requirenient of all criminal offenses. ${ }^{39}$ The argument for constitutionalizing

27. Powell v. Texas, 392 U.S. 514 (1968) (holding conviction for public drunkenness of one compelled to drink is not cruel and unusual punishment).

28. Furman v. Georgia, 408 U.S. 238 (1972) (invalidating Georgia death penalty law as arbitrary and capricious).

29. Gregg v. Georgia, 428 U.S. 153 (1976) (upholding revised death penalty statute based on scheme of guided discretion).

30. Mullaney v. Wilbur, 421 U.S. 684 (1975) (holding Maine law placing burden on defendant to prove heat of passion or sudden provocation violates due process).

31. Patterson v. New York, 432 U.S. 197 (1977) (placing burden on defendant to prove affirmative defense of extreme emotional distress does not violate due process).

32. Solem v. Helm, 463 U.S. 277 (1983) (holding sentence of life imprisonment with no possibility of parole for nonviolent offense prohibited by the Eighth Amendment).

33. Hurmelin v. Michigan, 501 U.S. 957 (1991) (holding mandatory life sentence with no possibility of parole for possession of more than 650 grams of cocaine is not cruel and unusual punishment).

34. Grady v. Corbin, 495 U.S. 508 (1990) (holding double jeopardy bars subsequent prosecution where prosecution must rely on proof of conduct that constituted an offense for which the defendant was already prosecuted).

35. United States v. Dixon, 509 U.S. 688 (1993) (holding ban on double jeopardy does not require that subsequent prosecutions satisfy a "same conduct test").

36. 355 U.S. at 225.

37. United States v. Park, 421 U.S. 658 (1978) (affirming, in general, validity of strict liability laws).

38. See William J. Stuntz, Substance, Process, and the Civil Criminal Line, $7 \mathrm{~J}$. ConTEMP. LEGAL IssuEs 1 (1996) (discussing relation between criminal procedure and substantive criminal law).

39. See, e.g., Larry Alexander, The Supreme Court, Dr. Jekyll, and the Due Process of Proof, 1996 SuP. CT. REv. 191; Gary V. Dubin, Mens Rea Reconsidered: A Plea for a Due Process Concept of Criminal Responsibility, 18 Stan. L. Rev. 322, 392-95 (1966); C. Peter Erlinder,Mens Rea, Due Process, and the Supreme Court: Toward a Constitutional Doctrine of Substantive Criminal Law, 9 AM. J. CRIM. L. 163, 165-66 (1981); Hart, supra note 4, at 422-25; James J. Hippard, Sr., The Unconstitutionality of Criminal Liability Without Fault: An Argument for a Constitutional Doctrine of Mens Rea, 10 Hous. L. Rev. 1039, 1039-40 (1973); John C. Jeffries \& Paul B. Stephan III, Defenses, 
the notion of an offense presented here, however, will not be based on the disparity between substance and procedure. Nor will it be based on the idea that only culpable agents should be punished. Instead, this Article will argue for the need for a substantive theory of offense definition by considering two inuportant constitutional guarantees: the presumption of innocence and the ban on double jeopardy. Under the positivistic approach to offense definition, both doctrines have beconie entirely subject to legislative discretion. Something peculiar is at work, however, when the extent of a constitutional guarantee that ought to limit the reach of the criminal sanction is determined by the legislation establishing the sanction itself. While there are constitutional theories that would consider the statutory indebtedness of these doctrines a virtue ${ }^{40}$ the more widely shared understanding of constitutional rights is that they provide protection for individuals against their government rather than a constitutional imprimatur for legislative judgment. ${ }^{41}$

The kind of substantive limitation for which this Article will argue applies to the required criminal conduct instead of the mental state-the actus reus rather than the mens rea. This Article suggests that constitutionalizing the conduct instead of the mental state requirement-the "special," rather than the "general" part-will provide a more compelling source of limitation on offense definition. ${ }^{42}$ Mental state requirements do not restrict what a legislature can criminalize. For this reason, they do not by themselves significantly enhance the freedon of individuals from unwanted governmental intrusion. If there is a constitutional presumption against the use of the criminal sanction, then, it cannot be overconie by showing that the defendant engaged in the prohibited conduct with a certain mental state.

The presumption of innocence and the ban on double jeopardy strongly suggest the need for some substantive theory of offense definition. A more robust theory of these constitutional guarantees, however, would einerge from any number of nonpositivistic accounts of the notion of an offense. The latter half of this Article will attempt to provide the outlines of one such theory, based on the fact that criminal legislation is libertyinfringing. The claim is that the more a statute infringes the basic right to liberty, the stronger the presuinption against it, and hence the greater the justification required to vindicate its use. This Article will argue that the

Presumptions, and Burden of Proof in the Criminal Law, 88 YALE L.J. 1325 (1979); Michaels, supra note 6; Herbert L. Packer, Mens Rea and the Supreme Court, 1962 SuP. CT. REv. 107, 107-10.

40. See infra Part III (discussing the "positivist" theory of due process).

41. See Daniel A. Farber et al., Cases and Materials on Constitutional Law 383 (1993) (presenting origin of constitutional rights as belief in natural entitlenents enforceable against legislatures).

42. See LEO KATZ, BAD ACTS AND GuILTY MINDS 2 (1987) (explaining distinction between general and special parts of criminal law). 
correct substantive account of the notion of an offense is provided by determining when the use of the criminal sanction overcomes this presumption. While all legislation is liberty-infringing in at least a weak sense, the degree of infringement is usually sufficiently minor that the interference can be easily justified by considerations of instrumental rationality, in conjunction with a permissive test for the legitimacy of legislative aims. This Article suggests, however, that since criminal legislation is highly invasive of liberty, the mere demonstration of a measure's instrumental rationality ought not to be thought sufficient to overcome the presumption against it.

Parts I and II explain the difficulties with the positivistic understanding of the notion of an offense as used in the presumption of innocence and the ban on double jeopardy, respectively. These doctrines observe some striking similarities, for the positivistic understanding of an offense at the heart of both has engendered both similar patterns of reasoning and similar difficulties in the two areas. In particular, we see a certain proposal among commentators for avoiding the collapse of these guarantees into statutory concepts but that would allow courts to remain faithful to the positivistic orthodoxy about the notion of an offense. Parts I and II argue that these intermediate accounts fail where both doctrines are concerned, and that they fail for the same reason. Both Parts conclude that the constitutional doctrine in question cannot be meaningful as a source of protection unless independent constitutional content can be given to the notion of an offense.

Part III considers the various cases in which the Court has developed either implicit or explicit substantive limitations on offense definition. Drawing on certain common themes that appear in these rather disparate areas of law, this Part proposes a jurisprudential franework for developing a nonpositivistic understanding of the notion of an offense. In particular, this framework should make it possible to develop a more stringent account than courts traditionally require of when legislation involving significant infringenents of liberty is justified. It might allow us to say, for example, that a liberty-infringing measure is not justified if there is a substantially less invasive measure the legislature could have adopted to accomplish the sane end.

Part IV begins by considering a theory that would justify use of the criminal sanction to prevent or punish immoral acts, a theory sometimes referred to as "legal inoralism." 43 While legal moralism improves on the current positivistic orthodoxy, it remains open to a number of important objections. This Part then explores an alternative based on a different theory of justification, naniely the idea that the function of the criminal law is the protection of the community from those activities that inflict harm on others. The "harm principle," as it is often called after John Stuart Mill's

43. See HART, supra note 1, at 6; see also MoORE, supra note 1, at 69-70. 
famous argument for the legitimacy of government ${ }^{44}$ rivals legal moralism as a basis for developing an appropriate theory of justification for the use of the criminal sanction. From this theory of justified punishment, it may be possible to derive the proposed constitutional constramts on the notion of an offense. Finally, Part V returns to the two constitutional guarantees that first led us to question the positivistic approach to offense definition. It atteinpts to sketch-inevitably in extremely limited detail-how the proposed limits on the use of the criminal sanction might be used to revise each of these constitutional doctrines.

This Article will necessarily paint with very broad strokes, and no doubt it will fail to do justice to a number of doctrinal questions, burdens of proof and double jeopardy in particular. But understanding the relation these doctrines bear towards the notion of an offense should help to raise doubts about the Court's increasingly positivistic orientation. The full development of an alternative theory of offense definition, however, is beyond the scope of this Article.

\section{Positivism About the Presumption of InNocence}

The presumption of innocence was constitutionalized with the case of In Re Winship, ${ }^{45}$ which held that the Due Process Clause rcquires proof beyond a reasonable doubt " "of every fact necessary to constitute the crime charged." " The Court created no end of difficulties, however, by failing to specify how to identify such a fact. The natural interpretation is that the phrase refers to the elements of an offense. But how to decide what constitutes an element of an offense? If the concept is interpreted broadly, anything bearing on a defendant's liability to punishment could be part of the offense definition, in which case the constitutional protection Winship affords would be extensive. If understood narrowly, however, the prosecutorial burden could be reduced to the most minimal facts, leaving the state free to shift the burden with respect to any number of issues that might bear on the defendant's risk of punishment. It is puzzling that the Winship Court did not attend to this difficulty, for the rule that the prosecution must prove every element of an offense manifestly has no determinate content of its own. Its meaning must derive from the underlying concept of an offense one adopts.

The now orthodox solution to this problem arrived with Patterson $v$. New York. ${ }^{47}$ That case involved a New York homicide statute that reduced

44. JohN STUART MiLL, ON LIBERTY (Norton Critical Edition, 1975) 10-11 (presenting principle that establishes the avoidance of harm as the only legitimate grounds for exerting power over others).

45. 397 U.S. 358 (1970).

46. Id. at 363 .

47. 432 U.S. 197 (1977). 
the charge from murder to manslaughter if the defendant could prove by a preponderance of the evidence that he had killed under the influence of extreme emotional disturbance. ${ }^{48}$ The Patterson Court upheld the burdenshifting provision, interpreting Winship's guarantee as applying only to those facts the legislature had chosen to treat as elements of the offense. ${ }^{49}$ Since the Due Process Clause does not tell a state how to draft its murder and manslaughter provisions, the Court reasoned, the legislature is under no obligation to provide a given defense. And if the legislature can refuse to grant a defense, then surely it can choose to provide it but place the burden on the defendant to prove it. ${ }^{50}$ The Patterson position on burdens of proof thus follows directly from its positivistic understanding of the notion of an offense: If an offense is whatever the legislature chooses to prohibit, and an element is simply one of the components the legislature uses to define the offense, it follows that the legislature has plenary power to determine the parameters of the requirement that the prosecution prove every element of an offense beyond a reasonable doubt.

The decision came as a bit of a shock to commentators, for Patterson eviscerated Winship, given that it effectively eliminated any restrictions Winship had placed on the criminal statutes legislatures can draft. ${ }^{51}$ Legislatures could now obviate the presumption of innocence with respect to a given element simply by excluding it from the definition of the offense, and either converting it to an affirmative defense or eliminating it entirely. After Patterson, Winship amounts to the right to be presuined innocent with respect to whatever elements of an offense the legislature chooses to presume a defendant innocent. Justice Powell does not appear to have overstated matters when he wrote in dissent:

A limited but significant check on possible abuses in the criminal law now becoines an exercise in arid fornalities. What Winship ... had sought to teach about the limits a free society places on its procedures to safeguard the liberty of its citizens becomes a rather simplistic lesson in statutory draftsmanship. ${ }^{52}$

The potentially far-reaching effects of its decision were not entirely lost on the Patterson majority, which reluctantly admitted that its position "may seem to permit state legislatures to reallocate burdens of proof by labeling as affirmative defenses at least some elenients of the crimes now

48. See id. at 198-99.

49. See id. at $210-11$.

50. See id. at 211.

51. For criticisms of Patterson, see Marina Angel, Substantive Due Process and the Criminal Law, 9 Loy. U. CHI. L.J. 61, 93-111 (1977); Mark W. McLane, The Burden of Proof in Criminal Cases: Mullaney and Patterson Compared, 15 CRIM. L. Bull. 346 (1979); Irene M. Rosenberg, Winship Redux: 1970 to 1990, 69 TEx. L. REv. 109, 116-17 (1990); and Note, Winship On Rough Waters: The Erosion of the Reasonable Doubt Standard, 106 HARv. L. REv. 1093, 1093-94 (1993).

52. Patterson, 432 U.S. at 224 (Powell, J., dissenting). 
defined in their statutes." ${ }^{53}$ But it sought to deny the charge, claiming that "there are obvious constitutional limits beyond which the States may not go in this regard." 54 It did not, however, attempt to specify what those constitutional limits might be, ${ }^{55}$ and the Court has done nothing to clarify the suggestion since. Most importantly, there is nothing in the logic of Patterson that suggests any restrictions on the power of legislatures to define offenses. For a limitation on offense definition would imply that there is some content to the notion of an offense that a legislature is constitutionally obligated to capture. This, however, is precisely what Patterson denies.

The pre-Patterson regine, inaugurated a scant three years before Patterson effectively overruled it, had atteinpted to walk a middle line between full judicial oversight of criminal statutes and complete deference to state legislatures on the substantive doctrines of the criminal law. Mullaney $v$. Wilbur ${ }^{56}$ concerned a challenge to a Maine homicide statute which, like the New York provision considered in Patterson, shifted the burden of persuasion on the defense of provocation to the defendant. The Court held that the burden-shifting provision did violate the Winship requirenent, finding that the absence of provocation was a fact necessary to constitute the crime of murder. ${ }^{57}$ Justice Powell suggested that the difference between murder and manslaughter in terms of stigmatization and restrictions on personal liberty is so significant that it "may be of greater importance than the difference between guilt or innocence for many lesser crimes." 58 Thus despite the fact that the Maine provocation provision was formally structured to reduce the grade and degree of the offense for sentencing purposes, the Mullaney Court used a substantive test to determine that its absence is an element of the offense of murder. Any other approach, Justice Powell argued, would leave a legislature free to characterize a matter essential to the definition of an offense as bearing only on the extent of punishment. ${ }^{59}$ Winship, he argued, was concerned with "substance rather than this kind of formalism." It was, however, precisely this kind of formalism that the Court endorsed so soon thereafter.

53. Id. at 210 .

54. Id.

55. It gave the example of a state legislature that wanted to declare an individual guilty of a crime, suggesting that this would overstep the constitutional boundaries in question. See id. at 210 . But of course a piece of legislation of this sort would be unconstitutional for reasons other than those provided in Winship. It is not clear, then, whether Winship itself can be thought of as placing any limitations on the kind of criminal statutes legislatures draft.

56. 421 U.S. 684 (1975).

57. See id. at 703-04.

58. Id. at 698 .

59. See id. at 698-99.

60. Id. at 699 . 
Despite its focus on substance over form, the Mullaney Court did not question basic positivistic premises about offense definition. This is clear from the majority's insistence that the permissibility of burden-shifting provides only a framework for interpreting criminal statutes where the legislature has chosen to equip defendants with certain defenses. It does not place the legislature under an obligation to provide defendants with any such defense in the first place. ${ }^{61}$ As Justice Powell wrote in his Patterson dissent:

The Winship/Mullaney test identifies those factors of such importance, historically, in determining punishment and stigma that the Constitution forbids shifting to the defendant the burden of persuasion when such a factor is at issue. Winship and Mullaney specify only the procedure that is required when a State elects to use such a factor as part of its substantive criminal law. They do not say that the State must elect to use it.... [N]othing in Mullaney or Winship precludes a State froin abolishing the distinction between murder and manslaughter and treating all unjustifiable homicide as murder. ${ }^{62}$

It is not implausible to suppose that it was this aspect of Mullaney, however, that contributed most to its early demise. For the attempt to articulate constitutional limits on the power of states to engage in burden shifting without constitutionalizing the underlying matter under consideration is inherently unstable, since, as Patterson insisted, the greater power to determine whether to grant a certain defense in the first place implies the lesser power to determine the burden of proof with respect to that element. ${ }^{63}$ By refusing to articulate general constitutional limitations on the nature of criminal offenses, Mullaney failed to provide a theoretically sound basis for constitutionalizing the line between offense elements and affirmative defenses. ${ }^{64}$

61. See id. at 698.

62. Patterson, 432 U.S. at 228 (Powell, J., dissenting).

63. As the Patterson majority recognized, "[t]he Due Process Clause ... does not put New York to the choice of abandoning those defenses ... in order to convict of a crime which otherwise is within its constitutional powers to sanction by substantial punishment." Id. at 207-08; see also Martin v. Ohio, 480 U.S. 228 (1987) (holding that placing the burden of proving self-defense on defendant does not violate the Due Process Clause of the 14th Amendment).

64. Some commentators, however, object to the "greater power includes the lesser power" argument. The problem is supposed to lie with the premise that a legislature may permissibly pass any measure whose permissibility is implied by an existing power it has. From the fact that a legislature has a certain power it does not follow that it would ever exercise that power, given that it may be politically infeasible for it to do so. See Ashford \& Risinger, supra note 15, at 178. It is as though someone were to argue that a patently unconstitutional law was constitutional because Congress has the power to amend the Constitution to make it constitutional. 
Commentators for their part have mostly reviled Patterson and sided with Mullaney. ${ }^{65}$ But the literature suffers from an unclear view of the alternatives. Commentators reject Patterson because they think it possible to articulate intermediate limitations on the power of legislatures to engage in burden-shifting without working a radical revision of the powers of federal courts to review the content of crimmal legislation. But the "greater power implies the lesser power" argument is arguably fatal to all solutions of this type. That is, if the argument of Patterson is correct, there is no consistent principle to which courts could turn to impose constitutional limitations on the power of legislatures to shift burdens of proof in isolation, without controlling their right to define offenses.

In light of the foregoing, it is regrettable that most commentators who reject Patterson's positivism nevertheless do not argue for constitutional oversight of offense definitions. Instead they continue to search for soine sort of intermediate principle, one that would constitutionalize burdens of proof without constitutionalizing the underlying offense definition. Barbara Underwood, for example, has argued for a constitutional principle that would attach the reasonable doubt rule to those factors that serve to establish individual "culpability." defendant's blameworthiness should count as part of the offense definition. The focus on blameworthiness can itself be explained in terms of the purpose the presumption of innocence should be taken to serve, namely to compensate for the unequal resources and power of the state "by putting a thunb on the defendant's side of the scales of justice."67

Another solution in this genre is one proposed by Donald Dripps. Here the purpose served by the presumption of innocence has to do with the constitutional requirement of notice. ${ }^{68}$ According to Dripps, every eleinent that makes a difference to a defendant's guilt or innocence (whether cast as offense element or affirmative defense) is subject to the Winship restriction, on the grounds that the principle of legality forbids the punishment of those who have not violated the law by its enunciated terms. ${ }^{69} \mathrm{Like}$ Underwood, Dripps atteinpts to treat the problein of burdens of proof in

65. See, e.g., Nelson E. Roth \& Scott E. Sundby, The Felony Murder Rule: A Doctrine at Constitutional Crossroads, 70 CoRnelt L. Rev. 446, 463 (1985). But see Ronald J. Allen, The Restoration of In re Winship: A Comment on Burdens of Persuasion in Criminal Cases After Patterson v. New York, 76 Mich. L. REv. 30 (1977) (arguing Mullaney extended due process protection too far, and Patterson was a correction of the Court's error).

66. See Barbara Underwood, The Thumb on the Scales of Justice: Burdens of Persuasion in Criminal Cases, 86 YALE L.J. 1299, 1340 (1977). Underwood appears to understand culpability in a way that makes it co-extensive with "wrongfulness," rather than in the more technical sense criminal law scholars usually have in mind, which makes it a synonym for mens rea.

67. Id. at 1306.

68. See Donald A. Dripps, The Constitutional Status of the Reasonable Doubt Rule, 75 CALIF. L. REv. 1665 (1987) (arguing for notice-based theory of burdens of proof).

69. See id. at 1667. 
isolation, separating it from the more general question of the parameters of the underlying offense.

What these various "intermediate" solutions share is an instrumentalist interpretation of the presumption of innocence, namely an interpretation that makes the reasonable doubt rule a procedural device designed to increase the likelihood of promoting some other value the presumption of innocence is thought to serve..$^{70}$ The presumption of innocence is not, under this renderimg, a requirement of constitutional justice in its own right. It is required only insofar as it promotes some other principle commentators deein more fundamental. Ironically, the instrumentalist approach to burdens of proof is as much a consequence of positivistic thinking about the notion of an offense as is Patterson's complete deference. For on a substantive conception of an offense, Winship does not require the addition of a further, external value to supply the doctrine its significance. Against the background of a substantive understanding of the notion of an offense, the rule that the presuniption of innocence applies to every element of an offense has its own meaning. Once one has accepted the basic positivist premise, however, commentators who seek a way of preserving Winship are left with a seemingly impossible task. As Dripps aptly explains: "The challenge, then, is to identify a constitutional proof requirement independent from any constitutional requirement of what is to be proved."71

Ronald Allen has argued forcefully against instrumentalist accounts:

If the constitutional interest in the reasonable doubt standard centers on liberty deprivation, how can the addition of a chance to mitigate constitutional punishment invalidate the statute? Or, to put it another way, if a state may constitutionally imprison all intentional murderers for thirty years by proving beyond reasonable doubt only intent and causation, then whatever liberty interest the defendant constitutionally possesses in the context of homicide prosecutions surely is fully accommodated by such a statute. How, then, can the addition of a nitigating circumstance in the form of an affirmative defense-a factor that reduces punishment-possibly violate the already fully accommodated interest? ${ }^{72}$

But even commentators like Allen who are moved by the "greater power implies the lesser power" argument of Patterson do not necessarily endorse a substantive approach to offense definition. Allen, for example, proposes what he calls the "proportionality" approach, according to which

70. See id. at 1677.

71. Id. at 1713. Although the Patterson majority attempted to distinguish the two statutes, its efforts in this regard were unconvincing. The Patterson Court's attempt to distinguish Mullaney relied on the fact that the Maine statute made the defense of provocation a condition of sentencing, whereas the New York statute made it a clear affirmative defense.

72. Allen, supra note 65 , at $42-43$. 
a state may shift the burden on any element as long as the sentence authorized for the remaining elements of the offense lies within the bounds of Eighth Amendment proportionality constraints. ${ }^{73}$ The Supreme Court, however, has now largely eliminated proportionality review outside the death penalty area. ${ }^{74}$ If proportionality is to supply the line between offenses and defenses, the concept would have to be restored to our Eighth Amendment jurisprudence and even extended beyond its former glory. ${ }^{75}$ So nuanced and detailed a theory of legitimate pumishment under the Eighth Amendment is not only unlikely to develop, but also would invade legislative prerogative to a far greater extent than would a substantive doctrine of offense definition. If it is possible to approach burdens of proof by articulating limits on offense definition instead, we could accomplish the basic aim of Allen's approach with less revision of existing doctrine.

This discussion of the presumption of innocence reveals a tension in the American legal systein's understanding of the notion of an offense. On the one hand, there is the officially sanctioned theory of offense definition, one that says that legislatures have plenary power to determine the boundaries of crime, at least to the extent that the use of the criminal sanction does not unduly interfere with a fundamental constitutional right. On the other hand, a procedural principle that is central to our constitutional jurisprudence depends on the notion of an offense, and that doctrine makes little sense as a protection for individual liberty unless the notion of an offense can be rendered meaningful independent of the criminal statutes it is meant to guide. The standard response to this tension has been to attempt to split the difference-to identify values external to the notion of an offense that the reasonable doubt rule is supposed to vindicate. But, as we have seen, theories that do not tie the presumption of innocence to a substantive notion of an offense leave the constitutional guarantee a rather thin one, given that it depends for its content on the good graces of state legislatures.

73. There is only one other alternative to Patterson, as Allen sees it. This is the "political compromise" theory, which attempts to determine whether the legislature only decided to adopt the defense in question on the condition that it was able to shift the burden with respect to that element. See id. at 49-50. Allen suggests that the Patterson court did not in fact intend to establish an elements test, as is commonly supposed, but that its preferred approach was the proportionality theory Allen himself favors. See id. While there is little evidence for Allen's interpretive claim about Patterson, he seems correct to favor a proportionality approach over both the approach the Patterson Court actually took, which is an elements test, and the political compromise approach.

74. See Harmelin v. Michigan, 501 U.S. 957 (1991) (finding mandatory life sentence without possibility of parole for cocaine possession does not violate the 8th Amendinent's protection against cruel and unusual punishment).

75. See Solen v. Helm, 463 U.S. 277 (1983) (concluding the right to be free from disproportionate punishment guaranteed by the 8th Amendment). 
II

\section{Positivism About Double Jeopardy}

A second constitutional guarantee, the ban on double jeopardy, also depends on the notion of an offense. In this case, the guarantee's indebtedness to this notion is textually grounded. The Fifth Amendment prohibits placing a person in jeopardy of life or limb twice for "the same offense." This clause is thought to prohibit reprosecution of a defendant on charges for which he has already been either acquitted or convicted in a prior proceeding, as well as for multiple punishment awarded in a single proceeding for the same offense. ${ }^{77}$ The overwhelming emphasis in both case law and commentary is on the former, the ban on successive prosecution. ${ }^{78}$ The ban on multiple punishment, by contrast, has remained largely undeveloped. The dominant view of the latter seems to be that it is merely a way of ensuring that a person convicted of a crime receive only the legislatively prescribed punishment. ${ }^{79}$ By contrast, a distinct set of constitutional values, such as a defendant's interest in avoiding the cost and embarrassment of repeated trials, his interest in finality, and the apparent unfairness of artificially increasing the state's chance of convicting the defendant through multiple prosecutions, are believed to animate the ban on successive prosecution. ${ }^{80}$

The perceived asymmetry between the two branches of double jeopardy law is a product of the positivistic understanding of the notion of an offense. On the multiple punishment side, if the legislature has plenary power to define offenses, the constitutional prohibition on double jeopardy has no content of its own. It merely serves to emphasize the legislatively established upper limit on pumishment. On the successive prosecution side, by contrast, the doctrine has more content, since it bars a prosecutor who

76. U.S. CONST. amend. V.

77. See North Carolina v. Pearce, 395 U.S. 711 (1969).

78. Recent notable examples of the latter include Akhil R. Amar \& Jonathan L. Marcus, Double Jeopardy Law After Rodney King, 95 Colum. L. REv. 1 (1995); George C. Thomas III, Successive Prosecutions for the Same Offense: In Search of a Definition, 71 IowA L. Rev. 323 (1986); Peter Westen, The Three Faces of Double Jeopardy: Reflections on Government Appeals of Crininal Sentences, 78 Mich. L. Rev. 1001 (1980); and Peter Westen \& Richard Drubel, Toward a General Theory of Double Jeopardy, 1978 SuP. CT. REV. 81, 86.

79. See Missouri v. Hunter, 459 U.S. 359, 366 (1983) (holding nonconcurrent punishment awarded in a single trial for armed criminal action and first degree robbery does not violate Double Jeopardy Clause).

80. See George C. Thomas III, A Unified Theory of Multiple Punishment, 47 U. PITT. L. REv. 1, 1 (1985) ("[A]though both protections are created by the double jeopardy clause, the prohibition of multiple punishments is informed by different values and requires a different analysis than the protection against multiple trials."). It is concerned with sparing a defendant from repeatcd and harassing litigation, both because of the burdens of prosecution and because of the potential for artificially increasing the chances of conviction. It is also concerned with protecting a defendant's interest in finality, as well as in protecting his interest in having his trial completed by a particular tribunal. See also Westen \& Drubel, supra note 78, at 86 (articulating purpose of ban on successive prosecutions). 
had lost at trial from reprosecuting the defendant on precisely the same charges in order to try her luck with a different jury. But in neither case does the ban on double jeopardy have much intrinsic meaning. It does not, for example, prevent a legislature froin shaping its criminal prohibitions in a way that would obviate these restrictions. A legislature could thus effectively punish multiply or authorize multiple prosecutions for the "same offense," as long as it sliced its offense definitions finely enough. Courts and commentators atteinpt to answer these concerns by suggesting that the guarantee serves a set of further values that are external to the ban on double jeopardy itself. This response is the counterpart of the instrumentalist view of the presuinption of innocence we saw in the preceding Part. But the required external values appear to be present in the case of successive prosecutions but not in the area of multiple punishment. Hence the asymmetry between the two branches of double jeopardy law.

The crucial question in interpreting the ban on multiple punishment is when two offenses are the "same" within the meaning of the Double Jeopardy Clause. ${ }^{81}$ The prevailing test was articulated in Blockburger $v$. United States ${ }^{82}$ in which the Court said that two offenses are not the same for double jeopardy purposes if "each of the offenses created requires proof of a different element." ${ }^{\prime 3}$ Suppose the elements of burglary are "enter[ing] ... a building with purpose to commit a crime therein, ... unless ... the actor is licensed or privileged to enter ${ }^{34}$ and the elenients of criminal trespass are "if, knowing that he is not licensed or privileged to do so, [a person] ... enters ... any building." ${ }^{85}$ All the elements of the latter would be contained within the former. The two offenses thus fail the Blockburger test, making them the "same" for double jeopardy purposes. Armed robbery and bank robbery, by contrast, would pass the test, since each contaims an element the other does not contain: use of a weapon and robbery of a bank, respectively. ${ }^{86}$

Once again, the Supreme Court here evades the crucial question it evaded in interpreting Winship's mandate: When does a fact constitute an eleinent of an offense? And once again, the Court responds with the usual positivist shibboleth: The elements of an offense are whatever facts the legislature decides to require a prosecutor to prove by including it in the definition of the offense. ${ }^{87} \mathrm{Just}$ as this response left it open to legislatures to

81. This question is of great relevance for the ban on successive prosecutions as well.

82. 284 U.S. 299 (1932).

83. Id. at 304 .

84. Model Penal Code $\$ 221.1(1)$.

85. Id. § 221.2(1).

86. The Blockburger test is also sometimes referred to as the "same evidence" test, because it requires that each offense involve the production of evidence that the other offense does not require. If two offenses require proof of all the same facts, or if one offense requires proof of all the facts required also to prove a second offense, the two offenses are the "same" for double jeopardy purposes.

87. See Blockburger, 284 U.S. at 303-04. 
shift the burden with respect to an element by eliminating it from the offense defmition, here there is a drafting technique the legislature can use to obviate the ban on double jeopardy, particularly where multiple punishment is concerned. All a legislature need do is add nonoverlapping elements to each offense it wishes to punish separately, elements which may be irrelevant for identifying the evil the statute is designed to eliminate. In theory, for example, a legislature could distinguish bank robbery at the top of the hour from bank robbery at half-past, enabling it to assign separate, nonoverlapping punishments for any bank robbery that lasts over half an hour. The logic of Blockburger, the double jeopardy equivalent of Patterson, suggests nothing to disallow it. Once again, the positivistic approach to offense definition turns a constitutional guarantee that depends on the notion of an offense into a doctrine about fidelity to legislative intent.

One way of defending constitutional doctrines with the above structure is to see then as serving rule-of-law values. If the prosecution must prove every element of a statutorily defined offense beyond a reasonable doubt, individuals are on notice of the conduct they inust avoid if they wish to remain at liberty. And if they are law-abiding but are nonetheless charged and tried for a crime they did not commit, the presumption of innocence will inaximize the chance that they will be able to defend themselves effectively. Similarly, the ban on double jeopardy arguably protects individuals against their governments by providing some additional protection against lawless prosecution and punishment. The positivistic interpretation of these two constitutional doctrines is thus consistent with a view of constitutional guarantees as ensuring fairness in the process by which government invades the liberty of its citizens. But while it is not implausible to suppose that a constitutional provision could serve such a function, we would need an argnment for why we should understand these constitutional doctrines in particular as vindicating rule-of-law concerns. Indeed, the rule-of-law interpretation begins to look a bit strained when we consider that it would result in both constitutional guarantees serving the same function. Why, one might ask, would this function be served by two different provisions rather than by a single constitutional concept? Indeed, we already have a constitutional provision that seems more than adequate to the task: the Due Process Clause of the Fourteenth Amendment. Why would we have two additional doctrines designed to reinforce rule-of-law values as well, especially doctrines that purport to address entirely different issues?

Moreover, the rule-of-law interpretation turns out to be particularly difficult to maintain where the ban on double jeopardy is concerned. For the commitinent to positivism is unore entrenched here than in the presumption of innocence context. The Court has accomplished this by 
making even Blockburger-type manipulation of the elements of an offense unnecessary. In Missouri v. Hunter, ${ }^{88}$ the legislature had made it an offense to use a dangerous weapon in the commission of a felony, to be punished separately froin the underlying felony itself. The Court thus faced a situation in which the legislature had expressed a clear intention to impose nonoverlapping punishments for two offenses that were the "same offense" under Blockburger. ${ }^{89}$ The Hunter Court took the fmal step in the direction of positivism: It relegated the same elements test to a rule of statutory construction, making it applicable only where the legislature has not spoken to the relation between the two offenses. It thus left the legislature free to authorize multiple punishment for the "sanie offense," as long as it did so clearly and explicitly.

To see how revisionary this move was, consider the parallel in the burden-of-proof area. Imagine a Supreme Court decision that left a legislature free to presume the defendant guilty with respect to any element of an offense it wished, as long as it announced its intention to do so clearly and unambiguously. Would we not think a judge or commentator facetious who then insisted that the presumption of innocence had not lost its character as a constitutional guarantee, on the grounds that it still served ruleof-law values? Yet the imagined position on the presumption of innocence follows as seamlessly from Patterson as Hunter does from Blockburger. In both contexts, the more radical rule allows a legislature to do directly what it is constitutionally permitted to do indirectly anyway. It is not clear, then, what is to be gained from forcing a legislature to pass through the largely meaningless notion of an element of an offense. Why not dispense with the element fiction, as Patterson and Blockburger already allowed with respect to the concept of an offense, and let the legislature state its true intent clearly and nonformalistically? Indeed, the due process requirement of notice would appear to be better served this way, for at least legislatures would have to present the risk of conviction and the potential severity of punishment boldly, unobscured by Byzantine formalities.

Another argument we saw in defense of the positivistic approach to burdens of proof has a counterpart here. ${ }^{90}$ Surely, the argument goes, a legislature could authorize what announts to the saine thing as cumulative punishment simply by attachmg it to a single offense. If, for example, the use of a dangerous weapon in the commission of a crime is punishable by five years, and the underlying felony is punishable by ten, the legislature

88. 459 U.S. 359 (1983).

89. At least arguably cumulative punishment would have been banned, given the Court's fairly consistent approach to lesser-included offenses.

90. For the following argument, see George C. Thomas III, A Blameworthy Act Approach to the Double Jeopardy Same Offense Problem, 83 CALIF. L. REv. 1027, 1051-53 (1995) (arguing that legislature may authorize multiple pumshment for two offenses that are the "same" if it can punish either offense for the full amount separately). 
could reach the same result as if it could punish these two offenses cumulatively by authorizing fifteen years for either offense alone. If there is no Eighth Amendment impediment to a fifteen-year sentence for either offense taken separately, why should a legislature be barred from spreading the fifteen years over two separate crimes, where one is the lesserincluded offense of the other? Consider also whether a legislature could constitutionally pass a statute that made the penalty for bank robbery ten years, and then provided that anyone convicted of bank robbery will be punished twice. ${ }^{91}$ Assuming that a twenty-year punishment for bank robbery is not constitutionally excessive, it would be odd to suppose that a legislature could not write such a statute if it could permissibly authorize a twenty-year penalty for the same offense. Why, then, should a legislature be forbidden from authorizing cumulative punishment for two offenses that turn out to be the "same offense" under Blockburger? Once again, the "greater power implies the lesser power" argument provides support for the positivistic approach to the relevant constitutional guarantee.

Notice, however, that the same argument would be unacceptable in the successive prosecution context. For we would not want to conclude that a legislature could authorize multiple attempts at conviction, as long as it did so clearly and unambiguously. But the logic of Hunter could be made to apply to the ban on successive prosecutions as well. Surely, the argument would go, the legislature could authorize successive prosecutions for a single transaction by slicing its offense definitions very finely. It could, for example, distinguish the offense of armed robbery from that of bank robbery, and authorize separate and successive proceedings against someone accused of both offenses for a single course of conduct. Now assuming that the court is following the Blockburger test, the legislature could authorize successive prosecutions for these offenses, since each contains an element the other does not contain. It would seem to follow, according to the above argument, that the legislature could also authorize successive prosecutions if one offense were a lesser-included offense of the other, such as if one offense were armed robbery and the other robbery. And if there is no argument against this, then why should the legislature not be able to authorize successive prosecutions for a simple, noncomposite offense, say, allowing the state to have two chances, rather than one, of convicting a bank robber?

There have been a number of different attempts to avoid the first step on this slippery slope, that is, to prohibit multiple prosecutions for closely related offenses arising from the same transaction. There was, for example,

91. See generally Note, Twice in Jeopardy, 75 YALE L.J. 262, 302 (1965) (arguing that substantive double jeopardy does not limit a state legislature, but rather only the discretion of the courts). 
the brief reign of Grady $v$. Corbin, ${ }^{92}$ in which the Court imposed a substantive hurdle over and above the Blockburger test, barring a successive prosecution that would rely on the facts used to prove the offense of the previous prosecution. Grady involved a prosecution for manslaughter, which took place after the defendant had already pled guilty to a violation for the drunk driving that caused the death.$^{93}$ Blockburger alone would not have ruled out the second prosecution, since drunk driving is not a lesserincluded offense of manslaughter. The Court therefore sought to add a substantive dimension to the concept of "same offense" in order to forbid multiple proceedings in this context. ${ }^{94} \mathrm{Grady}$, however, was quickly overruled by United States $v$. Dixon, ${ }^{95}$ which effectively returned the law of successive prosecutions to the sinple Blockburger test. Commentators, too, have proposed various sorts of inandatory joinder rules to supplement Dixon. The most sensible of these would allow a second prosecution for a greater offense, one of whose lesser-included offenses was proven in the initial prosecution, when new evidence of the greater offense appears and the state was diligent in attempting to uncover such evidence at the time of the first prosecution. ${ }^{96}$ The defendant would then receive credit for time served under the first offense towards his pumishment for the second. The fact, however, that these patchwork additions have seemed necessary to achieve just results suggests that there may be a flaw in the basic doctrine. As in the burden-of-proof area, the contortions that seem necessary to protect the ban on double jeopardy reflect the need to inject substance into a doctrine that lacks it, due to the lack of substance in the underlying notion of an offense.

One further doctrinal ramification of the positivistic understanding of the notion of an offense perhaps serves to illustrate the difficulties of this approach even more clearly. This is the problem of the "unit of prosecution," namely how many different instances of a given offense the defendant's behavior exemplifies. Two offenses that are the "same" for double jeopardy purposes may be cumulatively punished if the defendant committed that offense more than once. Thus although murder and manslaughter are the "same" offense, a defendant can be punished for each separately if he has two victims. While the point is an obvious one, it is often hard to determine how many times a defendant committed the

92. 495 U.S. 508 (1990).

93. See id. at 510 .

94. There is also the collateral estoppel rule of Ashe v. Swenson, 397 U.S. 436 (1970) (establisling a mandatory joinder rule for two offenses when the second offense would relitigate facts used to establisl the first offense in an earlier prosecution). Justice Brennan has suggested a more emphatic version of this approach, namely that ail offenses arising out of a single transaction be prosecuted in a single proceeding. See id. at 453-54 (Brennan, J., concurring).

95. 509 U.S. 688 (1993).

96. See generally Amar \& Marcus, supra note 78. 
offense when the different instances of the offense occur during a single course of conduct. How, then, do we determine what counts as one violation of a prohibition and what counts as more than one? With homicide offenses the answer is easy: Each dead body corresponds to a different violation of the homicide offense, assuming that the other elements of the offense are satisfied. Other offenses, however, are more difficult to count. If a person shoots at another six times in quick succession, he can be charged with one count of attempted murder. If he takes one shot on each of six successive days, however, he can be charged with six counts of attempted murder. How, then, should we individuate different instances of the crime of attempted murder? ${ }^{97}$

The Court has not always grappled successfully with this problem. The leading case is Brown v. Ohio, ${ }^{98}$ in which the defendant stole a vehicle in Cleveland and was caught driving the car nine days later in Wickliffe. He was charged with "joyriding" in Wickliffe, and after serving a short jail term and paying a fime, he was charged with theft in Cleveland. The defendant tried to claim that the second prosecution was barred on double jeopardy grounds, since the Ohio theft statute contained all the elements of joyriding, an offense for which he had already been convicted. ${ }^{99}$ Here the Supreme Court missed what the Court of Appeals had ably understood: that even though joyriding and auto theft are the "same offense" for double jeopardy purposes, the defendant could be punished more than once if he committed that offense multiple times during the nine days he possessed the automobile. The Court of Appeals addressed the problem and found the second prosecution permissible on the grounds that it was based on a second imstance of the same offense. The Supreme Court, by contrast, appears to have overlooked the umit-of-prosecution problem. It found the second prosecution barred, on the grounds that "joyriding and auto theft ... constitute 'the same statutory offense' within the meaning of the Double Jeopardy Clause." ${ }^{100}$ The only allusion the Court made to the unit-of-prosecution problem was to say: "The Double Jeopardy Clause is not such a fragile guarantee that prosecutors can avoid its limitations by the simple expedient of dividing a single crime into a series of temporal or spatial units." ${ }^{101}$ The Court did indicate in a footnote, however, that matters

97. The author is indebted to Professor Larry Alexander, University of San Diego School of Law, for this example.

98. 432 U.S. 161 (1976).

99. See id. at 163-64.

100. Id. at 168 .

101. Id. at 169. In this opinion, the Court ran together the problems of "type" identity (whether or not the type of offense in question is the sanie in both cases) with the problem of "token" identity (whether there is one or more token of the type of act prohibited). The problem of cumulative pumishment for felony murder and one of its predicate felonies is an example of the former; the problem of determining how many instances of joyriding the defendant in Brown exemplifies is an example of the second. The ban on multiple punishment will forbid consecutive sentences if there is 
would have been different had the legislature specifically said that joyriding is a separate offense for each day the vehicle is operated without the owner's consent. ${ }^{102} \mathrm{Had}$ the Court seen the unit-of-prosecution problem more clearly, then, it probably would have adopted the positivistic approach here as well, namely that there are no constitutional restrictions on how many units of prosecution the legislature carves out of a single transaction.

Here too the unalloyed positivistic position produces counter-intuitive results. While we might easily allow that a legislature could create a different instance of joyriding for every day that a defendant retained a vehicle without its owner's consent, could it also create a different instance of that offense for every hour? Every minute? And if it could do so for joyriding, why not for theft? Could it establish a separate count of theft for each stone contained in a piece of jewelry, or a separate count for each different type of metal? While such divisions would probably not be attractive to a legislature drafting the laws of theft, there is nothing to rule then out under a positivistic approach to offense definition. Nor would there be any other constitutional provision to stand in the way of such a statute, assuming that the legislature had adequately publicized its bizarre statutory scheine.

In light of the difficulties the positivistic account engenders, it is surprising that courts and commentators have not found a substantive doctrine of offense definition inore attractive. One possible explanation for this is that they have studied each constitutional doctrine in isolation, with the result that their common core has gone unnoticed. Attempts to supply meaning for each constitutional guarantee have thus been localized within the constitutional doctrine in question, rather than spread over a wider constitutional structure. One commentator succinctly displays this tendency. He writes, "So the question coines down to the following: is there anything in the Double Jeopardy Clause definition of 'offense' that precludes the legislature from authorizing two convictions for a Blockburger greater and lesser offense? The answer is negative on the Court's Hunter analysis...."103 The saine argument appears in Suprente Court opinions as well. Justice Rehnquist, for example, once wrote: "To the extent that [a substantive] ... thesis assures that any particular criminal transaction is made up of a determinable number of constitutional atoms that the legislature cannot further subdivide into separate offenses, "it demands more of the Double Jeopardy Clause than it is capable of supplying."'104

only one token of a single type. It will allow the punishment if there are either multiple tokens of a single type, or if there is a single token of more than one type.

102. See id. at 169 n.8.

103. George C. Thomas III, Double Jeopardy 109 (1998).

104. Whalen v. United States, 445 U.S. 684, 701 (1980) (Rehnquist, J., dissenting) (quoting Westen \& Drubel, supra note 78 , at 113 ). 
But this reasoning is reminiscent of the drunk searching for his keys under a lamppost because, as he explains, the light is better. True, there is nothing in the Double Jeopardy Clause that constrains legislatures in defining offenses. There need not be. The Clause presupposes the concept rather than defines it. But assuming that the Double Jeopardy Clause fails to supply the meaning of the term "offense," must state law define it instead? Could the notion of an offense not come from elsewhere in the Constitution, in this way supplying a common definition that applies to any constitutional doctrine that relies on that notion? Among other reasons for searching for the meaning of "offense" outside the particular constitutional doctrine that employs it, we should expect the concept of an offense to possess the same meaning in whatever constitutional setting it appears. ${ }^{105}$

The next Part proposes that we look for the meaning of an offense in our constitutional tradition of liberty. It will argue that this tradition should ultimately yield a constitutional theory of offense definition, given the presumption that the right to liberty creates against the use of the criminal sanction. This Article, however, will not itself undertake the task of providing such a theory. Offering a complete theory of offense definition is a vast undertaking, one that requires careful exploration of a number of thorny problems in substantive criminal law, as well as a detailed exploration of the constitutional foundation for such a theory. This Article might be thought of as the preamble to that larger project. It attempts only to indicate where one might seek to establish such a theory in our constitutional tradition.

\section{III}

\section{LIBERTY AND THE LIMITS OF CRIMINAL OFFENSES}

Philosophical discussions of punishment often begin with the observation that because it involves the infliction of pain or other form of unpleasant treatment, punishment stands in need of justification. ${ }^{106}$ As H.L.A. Hart has written, "[T]he use of legal coercion by any society calls for justification as something prima facie objectionable to be tolerated only for the sake of some countervailing good." $\mathrm{p}$ A criterion of adequacy for any theory of punishment, then, is that it provides an account of when punishment overcomes the presumption against the moral legitimacy of the acts it involves. A utilitarian theory of punishment, for example, that did

105. See Akhil R. Amar, Intratextualism, 112 HARY. L. Rev. 747 (1999) (arguing for method of constitutional interpretation that makes use of appearance of same constitutional term in different contexts).

106. See Joel Feinberg, The Expressive Theory of Punishment, in Essays on Dolng AND Deserving 95-96 (1970); S.I. Benn, An Approach to the Problems of Punishment, 33 PhiLosophy 325 (1958); A.G.N. Flew, The Justification of Punishment, 29 PhILosophy 291 (1954); H.L.A. Hart, Prolegomenon to the Principles of Punishment, 60 Proc. ARISTOTELIAN Soc'y 1 (1959-60).

107. HART, supra note 1, at 20 (diseussing theories of punishment). 
not subtract the criminal's loss of utility from the overall social gains of punishment would fail to meet its burden of justification, since it would fail to show the practice as worthwhile in the face of the suffering it imposes. ${ }^{108}$

This Part will suggest a constitutional analogue of the philosophical claim about punishment, namely that a constitutional order premised on notions of individual liberty contains what we might call a "requirenent of justification" for the legitimate use of the criminal sanction. While the argument for this requireinent is prescriptive, rather than descriptive, this Part will also suggest that this framework allows for what we might call a normative reconstruction of many of the Court's decisions limiting the use of the criminal sanction. The suggestion will be that a number of cases im this category limit the use of the criminal sanction at least in part because the deprivation of liberty involved is not adequately justified by the purpose for which the legislation was enacted. The claim is not that the Court is explicitly adopting a heightened requirement of justification in such cases, but rather that this is one way to interpret and to unify a series of decisions that otherwise look ad hoc. The claim then is that this interpretive framework can be defended on normative grounds, as following from a constitutional regime's basic commitment to liberty.

One objection to this proposal will be that federal courts have not been thought permitted to engage in substantive oversight of ordinary legislation on liberty grounds for the last sixty years. ${ }^{109}$ Not all liberty interests, however, are created equal. Rejecting oversight of economic regulation on the basis of a generic due process right to liberty does not entail the rejection of substantive federal oversight of legislation infringing the right to be free from bodily restraint. Why must a person's interest in freedom of contract and his interest in freedoin of his physical person stand on the same footing simply because they both constitute forms of "liberty" under the Due Process Clause? Moreover, it is difficult to understand a number of the decisions striking down criminal statutes without thinking that the Court is willing to impose substantive limitations on the notion of a criminal offense that go beyond the minimal requirement of rationality. These cases suggest that despite the official rejection of liberty-based review, decisions like Patterson and Hunter ${ }^{110}$ may be out of sync with our implicit understanding of the relation between individual liberty and the use of the criminal sanction.

108. This is arguably the feature that condemns utilitarian accounts of punishment, since they are unable to exclude cases in which a murder's utility from killing exceeds the disutility the murder produces. In this case, punishing the offender would impose greater disutility than it would prevent.

109. At least the point is clear with respect to economic legislation. See GEOFFrEY STONE ET AL., Constitutional Law 834 (1996) ("Since 1937, the Court's abandonment of Lochner-style substantive due process review of economic regulation has been unequivocal.").

110. Missouri v. Hunter, 459 U.S. 359 (1983). 
The more specific legal basis for this argument has of course been shrinking in recent years, as the substantive reading of the due process liberty right becomes increasingly limited. Liberty, like property, is largely a formal category whose content must be determined by legislation. Decisions like Patterson reflect the piecemeal replacement of the substantive picture with quite a different one. The alternative picture of due process is fittingly sometimes referred to as the "positivistic" approach to due process. ${ }^{111}$ It maintains that the liberty and property interests protected by the Due Process Clause are positivistic concepts, the contents of which are supplied entirely by state law. The positivistic approach to due process makes the same point about the line between substance and procedure we saw in the burden-of-proof context, namely that it makes no sense to constitutionalize process without also constitutionalizing the underlymg substantive rules to which the process constraints apply. ${ }^{112}$ The conclusion, however, is precisely the reverse of the conclusion a substantivist about constitutional criminal law would reach: While the substantivist argues that this provides a reason to constitutionalize substance along with procedure, the due process positivist argues that it is a reason for federal courts to leave process to state legislatures as well. The result is a radically weakened conception of the Due Process Clause-the view that due process serves only to ensure that citizens receive those protections, whether substantive or procedural, that states have chosen to grant them in their lawmaking capacity. ${ }^{113}$

Judge Easterbrook, the central proponent of due process positivism, argues that the conceptual origins of the Due Process Clause support the positivist approach. He writes:

[T]he Due Process Clause places little or no legitimate restraint on the contents of legislation. Judges and Presidents must follow rules laid down in "law"; judges may not act ex parte in important matters; but Congress may establish as law such procedures as it pleases, subject only to the constraint that it not abrogate certain

111. Raoul Berger and Frank Easterbrook appear to be two of its central proponents. See RAoul Berger, Government By Judiciary: The Transformation of the Fourteenth Amendment (1997); Frank H. Easterbrook, Substance and Due Process, 1982 SuP. CT. Rev. 85; see also Louis D. Bilinois, Process, the Constitution, and Substantive Criminal Law, 96 MrCH. L. REv. 1269 (1998) (arguing against substantivist theories of due process). For a substantivist critique of due process positivism, see Martin H. Redish \& Lawrence C. Marshall, Adjudicatory Independence and the Values of Procedural Due Process, 95 YALE L.J. 455, 467 (1986) ("If all aspects of due process are open to legislative definition, then of what possible value is the constitutional guarantee of due process of law?"); see also Edward L. Rubin, Due Process and the Administrative State, 72 Cal1F. L. REv. 1044 (1984) (discussing positivistic renderings of due process).

112. See supra text accompanying notes $62-72$.

113. See Easterbrook, supra note 111. 
long-recognized judicial procedures when fundamental natural liberties are at stake. ${ }^{114}$

In our system, Easterbrook argues, specific provisions of the Bill of Rights replace the reference to fundamental natural liberties. As he explains, "All that is left are prohibitions designed to compel other departments of government to follow the legislature's plan."115 The weakness of the Due Process Clause under this interpretation is presented as a virtue, rather than an unfortunate necessity. According to the due process positivist, the Clause only has application if the executive branch falls imto tyranny or monarchy, smce its function is mainly to ensure that the executive conforms to the will of the legislature. In ordinary law-abiding times, due process has no function at all. Easterbrook cites as evidence for his view the fact that the Clause had little or no importance in federal cases for many years. As he explains, "The Due Process Clause escaped the Court's notice for the same reason it escaped the Framers': it stated an uncontroversial principle that was expected to be trivial."116

Easterbrook's argument against the distinction between procedure and substance is compelling. He suggests that it makes no sense to see courts as the arbiters of procedures designed to protect substantive rights if state legislatures have the fmal word on the content of those rights. Easterbrook argues accordingly that "the Court's due process cases are incoherent unless the Court has its own view of substance."117 He goes on to speculate that " $[t]$ he Court must be devising procedures that vindicate the Justices" views of the relative importance of different substantive entitlements, rather than legislators' views. Substantive and procedural due process turn out not to be so different."118 But the difficulty Easterbrook identifies can be solved im either the way favored by the positivists or the way favored by the substantivists. The former delegates both substance and procedure to state law, leaving due process to serve minimal rule-of-law values. The latter places substantive limits on legislatures where federal constitutional law controls the governimg procedure.

Bill Stuntz has argued in favor of the latter solution, on the grounds that "[f]or the foreseeable future, we will continue to live with a regime that (quite plausibly) treats criminal punishment as a different and specially serious deprivation of 'life, liberty, or property,' and hence one that should be subject to sigmificant constitutional regulation." 119 If we assuine the constitutionalization of criminal procedure, his concern is that substance will be distorted by legislatures precisely in order to obviate procedural

114. Id. at 98 (discussing Coke's view of the notion of due process).

115. Id. at 99 .

116. Id.

117. Id. at 115 .

118. Id.

119. Stuntz, supra note 38 , at 2. 
restrictions. Thus, if the substantive law is not fixed, constitutional restrictions on procedure will be vacuous. He writes:

The idea of treating the criminal sphere as constitutionally special may make a lot of sense, but if it does, it makes sense for process and substance alike. Indeed, the point is stronger: without substantive limits, important parts of the law of criminal procedure seem likely to fall apart. In a world in which prosecutors can choose whom to prosecute, special rules for criminal procedure logically require substantive limits on the law of crimes. Without such limits, the government's natural incentive is to evade or exploit the procedural civil-criminal line by changing the substantive civil-criminal line. The upshot is that we should either de-constitutionalize much of criminal procedure or create a kind of substantive due process for criminal law. ${ }^{120}$

Stuntz's argument for rejecting the positivistic solution and siding with a substantive approach is pragmatic. But the substantivist will probably need a stronger argument for rejecting due process positivism. For that position receives strong support from the fact that it would render the Court's positivistic decisions in the burden of proof and double jeopardy areas coherent. Furthermore, on no other conception of due process is this true.

The required argument may lie in the fact that due process positivism is out of keeping with a number of decisions in which the Court has articulated substantive boundaries on the use of the criminal sanction. It is beyond the scope of this Article to argue for a particular theory of the due process liberty interest, or even to offer a doctrinal account of specific due process decisions. But this Part will suggest that there is a strand of our constitutional jurisprudence that rejects the positivist understanding of the notion of an offense. In this way, the hope is to show that positivism about the notion of an offense is more costly than one might have thought, given that it would require the abandonment of important substantive limitations on offense defimition to which the Court has committed itself. There are thus substantive reasons for rejecting due process positivism, reasons of long standing in our constitutional tradition.

Consider, for example, the cases falling under the void-for-vagueness doctrine. As with many restrictions on the criminal sanction, the official doctrine clothes what are often substantive restrictions in formal garb. The vagueness doctrine purports to address the language in which criminal prohibitions are drafted, but many of the cases reveal a concern with what is drafted rather than how. Officially, the doctrine requires legislatures to word criminal provisions with sufficient specificity to avoid arbitrary police and prosecutorial enforcenent and to provide citizens with adequate notice of their exposure to criminal conviction. But often the Court's

120. Id. at $1-2$. 
concern with specificity of formulation evinces a substantive judgment about the harm the prohibition is meant to avert. This concern was apparent in Papachristou v. City of Jacksonville, ${ }^{121}$ where the Court struck down a Jacksonville ordinance identifying as vagrants a motley assortment of undesirable persons, from "rogues" or "vagabonds" to "persons who use juggling or unlawful games or plays," to "persons able to work but habitually living upon the earnings of their wives or minor children."122 The Court offered the usual two grounds for striking down legislation on vagueness grounds, namely that the statute failed to provide adequate notice and that it authorized arbitrary and erratic use of the police power. It suggested its concern with the overly invasive character of the legislation only obliquely, saying that the presumption of future criminality the ordinance creates "is too precarious for a rule of law." 123 This, as well as other aspects of the opinion, suggest that the Court's concern could not have been remedied by more careful drafting. More plausibly, the decision stemmed from a substantive judgment that both the quality and the quantity of interference with the targeted activities were too restrictive of liberty in light of the state's purposes. As Robert Post has written about this case, "[t]he Court could have argued that it was constitutionally forbidden to use judgments to impose 'lifestyle' norms on unwilling segments of the population, and the Court in fact trembled at the brink of just such a substantive due process analysis." 124

The use of the vagueness doctrine to limit overly invasive legislation was even clearer in Kolender v. Lawson, ${ }^{125}$ where the Court struck down an apparently much less offensive California statute requiring those stopped by police to furnish officers with "credible and reliable' identification." 126 The Court found the phrase unconstitutionally vague, on the grounds that it failed to specify the meaning of "credible and reliable." 127 Here the concern with the substance of the ordinance, and in particular with the fact that the infringement of liberty was insufficiently justified, was made explicit. Justice O'Connor wrote: “Our Constitution is designed to maximize individual freedoms within a framework of ordered liberty. Statutory limitations on those freedoms are examined for substantive authority and content as well as for definiteness or certainty of expression." ${ }^{128}$

121. 405 U.S. 156 (1972).

122. Id. at 163 (striking down Jacksonville Ordinance Code $\$ \S 26-57$ ).

123. Id. at 171 .

124. Robert C. Post, Reconceptualizing Vagueness: Legal Rules and Social Orders, 82 CALlF. L. REv. 491, 497 (1994).

125. 461 U.S. 352 (1983).

126. Id. at 353-54.

127. Id. at 353 .

128. Id. at 357 . 
The Court has recently used the doctrine of vagueness to articulate these concerns in particularly vivid colors. In City of Chicago $v$. Morales, ${ }^{129}$ the Court found a Chicago loitering ordinance unconstitutionally vague. Justice Stevens, in his opinion for the plurality, emphasized that Chicago's purpose of reducing the level of gang-related violence was legitimate:

The basic factual predicate for the city's ordinance is not in dispute. As the city argues in its brief, "the very presence of a large collection of obviously brazen, insistent, and lawless gang ineinbers and hangers-on on the public ways intimidates residents, who become afraid even to leave their hoines and go about their business. That, in turn, imperils community residents' sense of safety and security, detracts from property values, and can ultimately destabilize entire neighborhoods. ..."We have no doubt that a law that directly prohibited such intimidating conduct would be constitutional. ${ }^{130}$

But Justice Stevens went on to say that the ordinance was more invasive than necessary to accomplish this end. And he pointed out that it was not clear that the chosen method was even effective at reducing gang violence, and that there might be other inethods available. Of particular interest was the Court's reason for thinking the legislation vague and overly broad, namely that it infringed too extensively and unnecessarily a protected constitutional right to liberty. This, despite the fact that liberty itself is not a "fundamental right." Justice Stevens wrote:

[A]s the United States recognizes, the freedom to loiter for innocent purposes is part of the "liberty" protected by the Due Process Clause of the Fourteenth Amendment. We have expressly identified this "right to remove froin one place to another according to inclination" as "an attribute of personal liberty" protected by the Constitution. Indeed, it is apparent that an individual's decision to reinain in a public place of his choice is as inuch a part of his liberty as the freedom of inoveinent inside frontiers that is "a part of our heritage" or the right to move "to whatsoever place one's own inclination may direct" identified in Blackstone's Commentaries. ${ }^{131}$

Outside the area of vagueness, the Court was at its boldest and most explicit in the famous case of Lambert $v$. California. ${ }^{132}$ There the city of Los Angeles had made it a crime for any "convicted person" to fail to register with the police within five days of his or her arrival in Los Angeles, with each day's failure to register constituting a new violation. A

\footnotetext{
129. 119 S. Ct. 1849 (1999).

130. Id. at $1856-57$ (citations omitted).

131. Id. at $1857-58$ (citations omitted).

132. 355 U.S. 225 (1957).
} 
"convicted person" was anyone who had been convicted of a felony in California, or what would have been a felony in California if the conviction were from another state. ${ }^{133}$ No knowledge of the registration requirement was necessary. ${ }^{134}$ The Snpreme Court found that the provision violated due process. ${ }^{135}$ Although the Court allowed that the police power is "'one of the least limitable," it nevertheless stressed that "due process places some limits on its exercise." 136 In explaining that the statute failed to satisfy the constitutional requirement of notice, the Court pointed out that it criminalized conduct that is "wholly passive," and that "circumstances which might move one to inquire as to the necessity of registration are completely lacking." 137 The Court reinforced this basic substantive objection to the statute by quoting Oliver Wendell Holmes: "A law which punished conduct which would not be blameworthy in the average member of the community would be too severe for that community to bear." ${ }^{138}$

It is unfortunate that the Court did not make the grounds for its holding in Lambert clearer. Some commentators have interpreted it as precedent against the constitutionality of strict liability offenses. ${ }^{139}$ Others have emphasized the absence of a mistake-of-law defense, the fact that the statute sought to criminalize status, or the concern about arbitrary enforceinent that animated the Court's decisions in many of the vagueness cases. The deepest defect of the provision, however, was arguably that articulated in the influential amicus brief filed on Lambert's behalf. The brief said that the ordinance was an "unwarranted invasion of the right of privacy, right to liberty, and privileges and immunities of a citizen of the United States in that it penalizes a morally innocent and passive status and is not reasonably restricted to the evil with which it purports to deal." ${ }^{140}$ The affirmative conduct the ordinance demanded was so much of a departure from the criminal law's usual degree of intrusion into private life, and the justification for that departure so feeble, that the interference with liberty it involved was not justifiable.

Whether it was Lambert's influence, or simply the recurrence of the cluster of concerns that Lambert raised, subsequent due process decisions explored and expanded upon many of Lambert's basic themes. In a line of cases begnining with Robinson $v$. California, ${ }^{141}$ the Court's concern with the criminalization of status, for example, became explicit. A state law

133. See id. at 226 .

134. See id. at 227.

135. See id.

136. Id. at 228 .

137. Id. at 228-29.

138. Id. at 229 (quoting Oltver Wendell Holmes, THE COMMON LAW 50 (1883)).

139. See Packer, supra note 39, at 129-30.

140. Id. (quoting Brief of Amicus Curiae for Appellant, at 21).

141. 370 U.S. 660 (1962). 
making it a misdemeanor to "be under the influence of, or be addicted to the use of narcotics" 142 was at issue. The Court, finding the criminalization of status repugnant to the Eighth and Fourteenth Amendments, wrote:

It is unlikely that any State at this moment in history would attempt to make it a criminal offense for a person to be mentally ill, or a leper, or to be afflicted with a venereal disease. ... [T]n the light of contemporary human knowledge, a law which made a criminal offense of such a disease would doubtless be universally thought to be an infliction of cruel and unusual punishment in violation of the Eighth and Fourteenth Amendments. ${ }^{143}$

Although making a substantive comment about the permissible bounds of the use of the criminal sanction, the Court framed its concern gingerly. It defended the state's right to regulate narcotics traffic, and stressed the multiplicity of ways in which a state could seek to attack the drug trade without criminalizing status. ${ }^{144}$ The real problem with the measure, it suggested, was that the statute was more invasive of liberty than reasonably necessary to accomplish the state's end. The Court was not saying merely that the punishment for addiction was disproportionate to the offense. Its concern was more general. The Court suggested that the use of the criminal sanction was inappropriate for dealing with a problem like addiction. As the Court said: "Even one day in prison would be a cruel and unusual punishment for the 'crime' of having a common cold."145 True, the reach of Robinson was sharply limited thereafter by Powell v. Texas, ${ }^{146}$ in which the Court refused to treat public displays of alcoholism in a similar vein. The Court stressed, however, that liability here was based not on status but on the voluntary act of taking the first drink. ${ }^{147}$

Subsequent cases explored another issue raised in Lambert, namely whether a mistake-of-law defense is constitutionally mandatory. In Liparota $v$. United States, ${ }^{148}$ for example, the Court rejected the contention that a statute criminalizing the unauthorized transfer of food stamps could provide the basis for a criminal conviction without evidence that the defendant knew his conduct violated the law. It distinguished Liparota from the long line of cases rejecting a mistake-of-law defense, on the grounds that those cases criminalized "a type of conduct that a reasonable person should know is subject to stringent public regulation and may

142. Id. at $660 \mathrm{n} .1$.

143. Id. at 666 .

144. See id. at 664-65.

145. Id. at 667.

146. 392 U.S. 514 (1968) (upholding criminal statute criminalizing public drunkenness in application to an alcoholic).

147. See id. at 531 .

148. 471 U.S. 419 (1985). 
seriously threaten the community's health or safety."149 The Court suggested that a state could regulate drugs or hand grenades with strict liability, since the items are so manifestly threatening to the health and safety of the community that potential defendants are effectively on notice of their vulnerability to criminal prosecution. ${ }^{150}$ But a state cannot regulate nondangerous itenis such as food stamps in the same way. ${ }^{151}$ Here the Court was even more explicit about the relevance of the type of harm than it was in Robinson, $\mathrm{n} 1$ that it specifically made the availability of a given defense turn on the gravity of the harm the statute sought to prevent.

The foregoing cases mostly do not address the concern with liberty explicitly. The claim of this Part is accordingly not that these cases can be explained in terms of a doctrinal commitment to a general background right to liberty. Rather, the claim is that there is a jurisprudential framework within which these decisions would normatively cohere with a strand of our constitutional tradition. Another line of cases, however, is more explicitly concerned with liberty, namely the cases striking down legislation in defense of a supposed constitutional right to privacy. These cases address the problem of excessive governmental intrusion into the lives of individuals through a subsidiary constitutional value. While the fundamental right such cases address is officially privacy, not liberty per se, the distance between privacy and liberty is not very great. Protecting a right to privacy is another way of protecting citizens from excessive governmental interference. ${ }^{152}$

These concerns were perhaps most in evidence in the Court's opimion im Griswold $v$. Connecticut, ${ }^{153}$ where the majority found that the decision of whether to conceive a child "concerns a relationship lying within the zone of privacy created by several fundamental constitutional guarantees."154 The Court nrade the connection between privacy and liberty clearest when it stated that the Connecticut statute could not stand "im light of the familiar principle, so often applied by this Court, that a 'governmental purpose to control or prevent activities constitutionally subject to state regulation may not be achieved by means which sweep unnecessarily broadly and thereby invade the area of protected freedoms." 155 Justice Harlan, concurring in the majority's opinion, would have located the constitutionally protected

149. Id. at 433 .

150. See id.

151. See id.

152. As Ruth Gavison writes, "Privacy is derived from liberty in the sense that we tend to allow privacy to the extent that its promotion of liberty is considered desirable." Ruth Gavison, Privacy and the Limits of Law, 89 YALE L.J. 421, 451 (1980).

153. 381 U.S. 479 (1965)

154. Id. at 485 .

155. Id. (quoting NAACP v. Alabama, 377 U.S. 288, 307 (1964)). 
liberty interest in the Due Process Clause itself, rather than filtering it through a fundamental right to privacy:

In my view, the proper constitutional inquiry in this case is whether this Connecticut statute infringes the Due Process Clause of the Fourteenth Amendment because the enactment violates basic values "implicit in the concept of ordered liberty." For reasons stated at length in my dissenting opinion in Poe v. Ullman, I believe that it does. While the relevant inquiry may be aided by resort to one or more of the provisions of the Bill of Rights, it is not dependent on them or any of their radiations. The Due Process Clause of the Fourteenth Amendment stands, in my opinion, on its own bottom. ${ }^{156}$

Finally in Roe v. Wade, ${ }^{157}$ the Court again articulated the connection between privacy and liberty when it treated the concept of privacy as "founded in the Fourteenth Amendment's concept of personal liberty."158 Justice Stewart's concurring opinion endorsed the legitimacy of substantive review of criminal legislation, in light of the Harlan position on liberty. As he said:

[T] he Griswold decision can be rationally understood only as a holding that the Connecticut statute substantially invaded the 'liberty' that is protected by the Due Process Clause of the Fourteenth Amendment. As so understood, Griswold stands as one im a long line of . . . cases decided under the doctrine of substantive due process, and I now accept it as such. ${ }^{159}$

Like Justice Harlan, Justice Stewart would have recognized a broad "liberty" right in the notion of due process that covers more than those particular freedoms named im the Bill of Rights.

The classic statement of this position is of course Harlan's dissent in Poe v. Ullman. ${ }^{160}$ As he wrote:

[T]he full scope of liberty guaranteed by the Due Process Clause cannot be found in or limited by the precise terms of the specific guarantees elsewhere provided im the Constitution. This "liberty" is not a series of isolated poimts pricked out in terms of the taking of property; the freedom of speech, press, and religion; the right to keep and bear arms; the freedom from unreasonable searches and seizures; and so on. It is a rational continuum which, broadly speaking, includes a freedom from all substantial arbitrary impositions and purposeless restraints, ... and which also recognizes, what a reasonable and sensitive judgment must, that

156. Id. at 500 (Harlan, J., concurring) (citing Palko v. Connecticut, 302 U.S. 319, 325 (1937)).

157. 410 U.S. 113 (1973).

158. Id. at 153.

159. Id. at 168 .

160. 367 U.S. 497, 522 (1961) (Harlan, J., dissenting). 
certain interests require particularly careful scrutiny of the state needs asserted to justify their abridgment. ${ }^{161}$

Jurisprudentially, the Harlan conception of liberty captures a prevalent and compelling intuition, namely that human beings have a generalized right to liberty, or, as the point is often put, the right to be left alone. ${ }^{162}$ It is far beyond the scope of this Article to defend the Harlan conception of liberty. For present purposes, it is sufficient to point out that there is a strand in our constitutional history that supports a nonspecific understanding of that notion. The current, quite limited aim is simply to draw out the implications of this tradition for the notion of an offense, and to suggest the teusion in which it stands with the positivist orthodoxy. While Justice Harlan himself did not necessarily mean to establish a broad source of limitations on substantive criminal provisions, the background right to liberty for which he argued should still provide boundaries on the extent to which a state nay interfere with the right of its citizens to be free from bodily restraimt. The basic dividing line between the "Harlan substantivists" and the "Easterbrook positivists" thus emerges in response to the question whether the notion of "liberty" that the Due Process Clause protects is a formal concept, possessing only the content that state law gives it, or a federal constitutional norm, the boundaries of which federal law must articulate. The cases where the Court is called on to pronounce directly on the notion of an offense, like Patterson and Hunter, take the former position. The cases where the Court has placed substantive limits on the use of the criminal sanction appear to presuppose the latter.

This Article suggests that as long as there is a constitutional commitment to the notion of liberty in some form, then there is constitutional pressure to reject the positivistic conception of the notion of an offense. For it is the commitment to liberty that suggests at least a weak presumption against the use of the criminal sanction. From this it follows that the decision to criminalize is one that stands in need of justification. The most difficult challenge, of course, is to extract a specific substantive theory of offense defimition from this requirement of justification. But that is a task better reserved for a future occasion. Here it will suffice to see that the recognition of such a presuinption implies the availability of some theory of offense definition.

A constitutional theory of substantive criminal law must have answers to two questions: First, on what grounds are federal courts entitled to review criminal legislation pertaiming to the substantive doctrines of the criminal law for the adequacy of their content? Where the entitlements enumerated in the Bill of Rights are concerned the answer is obvious: The

161. Id. at 543 .

162. But see Ronald DworkIn, What Rights Do We Have?, in TAKING Rights SERIOUsLy 266, 268-72 (1978) (arguing against the idea of a generic right to liberty, as opposed to particular liberties). 
Constitution explicitly equips citizens with certain rights against their governments, such as the right to freedom of speech, and where legislation infringes one of these rights, federal judges may invalidate the legislation to protect the right if the state cannot justify the measure by reference to a "compelling state interest." But outside the area of fundamental rights the answer does not come easily. While the tradition of substantive due process provides the most likely source of these restrictions, due process positivism suggests that a legislature has unbounded discretion to decide what to criminalize and how to do so, as long as the statute does not infringe a fundamental right. Large portions of our constitutional jurisprudence of liberty, lowever, belie this suggestion. And if there is a general due process interest in liberty, then at least some of the justifications a state could offer for the use of the criminal sanction would fail to override the background right citizens have to be free from punishment.

The second question a constitutional theory of substantive criminal law must answer follows from the first: What, specifically, are the limits on the use of the criminal sanction that federal courts are entitled to enforce? When, in other words, is the legislature's reason for the infringement of liberty sufficiently powerful to rebut the background presumption against the use of the criminal sanction? The rationality requirement the Due Process Clause imposes on all legislation supplies the answer under current doctrine, but it should be clear that the minimal notion of rationality is madequate to explain the Court's liberty-protecting decisions.

Rationality review is usually understood as containing two separate tests: First, the legislature's end in passing the legislation must be "legitimate," and second, the legislation must be "rationally" related to this end. When is a means "rationally related" to the end? The answer the Court has generally adopted is that a statute is rationally related to the state's end when it tends to promote the end. The cases we have considered in this Part cannot plausibly be described as based on a failure of rationality. Instead, what appears to have driven the Court in these cases is the idea that legislatures may not mvade liberty more than is reasonably necessary to advance legitimate state purposes. This appears to be a particularly compelling way of understanding the vagueness cases. The prohibition on status offenses, the implicit limitations on strict liability, and even the cases articulating a fundanental right to privacy, arguably evince the same concern. In each case, the Court's primary objection appears to have been not that the legislature exceeded its authority by attempting to deal with problems like vagrancy, but rather that there were alternative means available to it that would be dramatically less invasive and would accomplish this same end.

The concern with the unnecessary invasiveness of liberty-infringing measures would help to explain the apparent difference between review in 
the criminal arena and review elsewhere. Arguably our Constitution cares about alternative means available to a legislature where liberty-infringing legislation is concerned, even though it does not care about this elsewhere. And this would make sense given the presumption against criminal statutes. Within certain broad outlines, this presumption ought not to be overcome unless the state can show it did not frivolously ignore a less libertyinfringing measure available to it. The idea that liberty infringements ought to be minimized thus points in the direction of a theory of offense definition. What one would need to identify is a minimnm set of elements for each offense that allows the offense definition to meet the above test. The decision to criminalize a given type of conduct would then meet its burden of justification if it can be shown that given the purpose of criminalizing that behavior, the measure adopted was roughly the least liberty-infringing formulation reasonably open to the legislature. Whether this suggestion can be made doctrinally compelling would require extensive further exploration. But the discussion of this Part should be sufficient to show that there are basic aspects of our constitutional jurisprudence that lend themselves to a substantive theory of offense definition. Positivism about the notion of an offense is not inevitable.

\section{IV}

\section{The Harm Principle}

The argument of the Article thus far has been that the liberty interest of citizens creates a presumption against the use of the criminal sanction, and that therefore criminal prohibitions stand in need of justification. In this way, we may be able to tease rough boundaries on the notion of an offense out of the right to liberty. The requirement of justification restricts a legislature in the conduct it may prohibit, as well as in the invasiveness of the prohibitions themselves. A criminal prohibition that failed to identify a harm of sufficient magnitude to overcome the presumption against it would be illegitimate, since it would constitute an unjustifiable interference with liberty.

Thus far, however, we do not have a picture of the kind of theory of offense defimition that would allow a court to determine when a legislature had met its burden of justification. To develop such a theory, we must "translate" the background right to liberty into a set of substantive principles for determining the legitimate use of the criminal sanction. This is accomplished by identifying a primciple or set of primciples that determines when a criminal statute satisfies its burden of justification. By specifying a theory of justification, it should be possible to identify a set of core elements for each legitimate offense. It should also be possible to determine when a state's purpose is insufficiently compelling to justify the decision to criminalize in the first place. We have thus arrived at a frainework for 
answering the question "What is a crime?" with which we began. A crime in a liberal order is prohibited behavior whose harmfulness justifies restricting a person's liberty in order to prevent or punish that behavior, according to whatever theory of justification that order accepts. To complete the definition, we must fill in the framework with a specific theory of justification.

One theory of justification is that provided by the legal moralist: The right to liberty may be limited only for the legitimate legislative purpose of punishing or preventing morally wrongful conduct. As Joel Feinberg characterizes this position:

The pure legal moralist in the strict sense demands that the law prevent and/or punish inherent immoralities even when they are harmless (because voluntary or consented to) and unoffending (because not forced on the attention of unwilling observers). He rests his entire case on the desirability of eliminating and preventing states of affairs whose evil, even though free-floating, is mtuitively inanifest and extreme. ${ }^{163}$

Under at least one version of this thesis, the legitimacy of that aim can be accounted for by a retributive theory of punishinent, and thus the background right to liberty is limited by the need to inflict pumshment deserved by wrongdoing. As Michael Moore defends this position,

[R]etributivism, when combined with the principle of legality and the insight that law as law does not even prima facie obligate citizen obedience, yields the legal inorality theory of proper legislative aim: all and only moral wrongs should be prohibited by the criminal law, for the reason that such actions (or mental states) are wrongful (or culpable) and deserve punishment. ${ }^{164}$

In Moore's version, the retributive principle of punishinent sets the boundaries of what he calls our "derived right to liberty," nainely the right not to have government regulate one's behavior for the wrong reason. ${ }^{165}$ The derived right to liberty establishes a link between a theory of punishment and the scope of liberty rights, for it is only if the criminal sanction is imposed for legitimate punitive ends that the derived right to liberty is adequately respected. For the legal moralist, the only legitimate punitive ends are supplied by the retributivist focus on moral wrongdoing. The legal inoralist's definition of an offense would thus be conduct that merits an infringement of liberty, in view of its fulfillment of the conditions of a retributive theory of punishmeut. According to the legal moralist, all and only immoral acts satisfy this condition.

163. 4 Joel Feinberg, The Moral Limits of the Crminal LaW: HarmLess Wrongdoing 8-9 (1988) (discussing broad and narrow senses of legal moralism).

164. MOORE, supra note 1 , at 754 .

165. Id. at 751 . 
There are, however, familiar arguments against legal moralism, particularly stemming from the difficulty of defending the tight connection between law and morality that theory asserts. First, there is the problem of accounting for mala prohibita crimes. While it is not implausible to think of the traditional common law crimes as targeting immoral acts, we cannot easily think of modern regulatory offenses in this way. Second is the problem of explaining why we fail to criminalize a number of acts that are manifestly immoral. Lyimg to a friend, backing out of a commitment, even cheating on a lover are normally not punishable, but they are usually thought immoral. These two objections to legal moralism have struck most scholars as sufficient grounds to reject that account of the notion of crime. Moore himself, however, has endeavored to defend legal moralism against them.

In response to the first difficulty, Moore suggests that mala prohibita crimes are ones in which the legislature aims instrumentally at some morally wrong act-type. Where mala in se crimes are concerned, the legislature includes the morally wrong act-type within the statement of the prohibition itself. Where inala prohibita crimes are concerned, by contrast, the legislature forbids an act because it tends to produce a morally undesirable state of affairs:

\begin{abstract}
Mala prohibita crimes are created to prevent some bad state of affairs from occurring. Driving a motor vehicle without a driver's license, for example, serves to prevent loss of life and other ijjuries to persons or property by keeping the unskilled, the ignorant, and the incapacitated off the roads. The morally ideal act-type is the one that maximally achieves this intrinsically valuable state of affairs.... There are thus still morally dictated act-types behind mala prohibita crimes even if such act-types are the product of instrumental calculation (rather than of the intrinsically wrongful nature of such act-types). ${ }^{166}$
\end{abstract}

Moore's solution, however, seems vulnerable to the following objections. First, it is not possible to identify a "morally ideal" act-type from an intrinsically valuable state of affairs; nor is it possible to identify a "morally dictated act-type" from a morally bad state of affairs. In each case, the problem is that there is no single type of act that is associated with the avoidance of that state of affairs. Consider the rule that requires people to defer to the driver on their right when cars simultaneously arrive at a four-way intersection. The undesirable state of affairs the rule is meant to avoid is a traffic accident. But any number of rules could naximally contribute to the avoidance of this state of affairs. For example, drivers could be required to defer to the driver on their left instead of on their right, or they could be instructed to defer to the largest vehicle, the

166. Michael MOORE, ACt AND CRIME 339-40 (1993). 
smallest vehicle, the brightest or the darkest, the newest or the oldest. In general, rules meant to facilitate coordination, which many mala prohibita offenses are, have a certain arbitrariness to the act-types they identify, for any number of act-types will maximally contribute to producing a certain end. ${ }^{167}$ How do we determine which act-type it is justifiable to prohibit and which it is not?

Another difficulty with Moore's solution is that mala prohibita crimes are often entirely unrelated to any item of moral concern. Moore is correct to suggest that mala prohibita crimes are designed to avoid undesirable states of affairs. But a state of affairs is not by itself an item of concern to morality. A traffic accident is, from a certain standpoint, an undesirable event, and the state of affairs in which such an accident has occurred is also undesirable, but so are headaches and avalanches. If avoidance of traffic accidents is a sufficiently morally worthy end to justify the use of the criminal sanction, then is not the avoidance of headaches and avalanches as well? It is not clear how exactly the legal moralist will accommodate mala prohibita crimes and still retain limits on the use of the criminal sanction.

In response to the second objection, Moore argues that while it is always a reason in favor of punishing an act that it is immoral, the reason need not be dispositive. Legislatures have other legitimate goals that may override their concern with morality. It is not clear, however, that the legal moralist can accommodate this modification. For if the immorality of the conduct is not a sufficient condition for criminalization in these de minimis cases, what reason is there to suppose that it is ever a sufficient condition? And if an act's immorality is never by itself a sufficient condition for prohibitimg it, the legal moralist's position may not ultimately stand apart from any number of other theories of criminalization, since many theories could take the position that an act's immorality is a necessary condition for criminalizing it and still think the moral status of an act relatively unimportant.

167. Moore's account of double jeopardy makes use of this framework. The essential idea is that two offenses are the "same" for double jeopardy purposes if they share the same morally salient acttype. See id. at 337. Consider, however, the above criticism as applicd to that account. In the case of crimes that are mala in se, a court trying to determine if two offenses are the "same" for double jeopardy purposes must locate the morally wrong act-type the legislature had in mind in drafting each offense, presumably whether or not the legislature has properly identified the act-type in question. Then a judge must decide whether the two offenses have a morally wrong act-type wholly or partially in common. If so, the two offenses cannot be punished cumulatively, and otherwise they can. But how is a judge supposed to identify the relevant act-type in the case of crimes that are mala prohibita, given that no ideal act-type can be inferred from the specification of a state of affairs as undesirable? If the acttype analysis means that a judge must look to ideally wrong act-types rather than to the elements of an offense, it is not clear how she is supposed to decide whether crossing the center median in a vehicle and reckless driving are the same offense. 
These arguments against the legal moralist are far from complete. ${ }^{168}$ Undoubtedly Moore would have compelling responses to them. Without purporting to have disposed of the legal moralist's approach to crime, we might nevertheless find these difficulties sufficiently worrisome to investigate an alternative. Instead of seeking to justify imterference with liberty by the need to punish morally wrong acts, one might think of the relevant justification as stemming from the harmfulness of the prohibited conduct. We might, in short, adopt the "harm principle" as the justification for interfering with liberty. In On Liberty, ${ }^{169}$ Mill wrote, "the only purpose for which power can be rightfully exercised over any member of a civilized community, against his will, is to prevent harm to others."170 The harm principle differs from legal moralism because the notion of harm is not necessarily connected with the moral character of the action that produces it. Accordingly, the avoidance of harm provides a morally neutral legislative aim, one, however, that seems capable of supplying a substantive justification for infringing liberty. And just as legal moralism suggests a retributive theory of punishment, so the harm principle implicates its own theory of punishment, one that serves to link the background concept of liberty with the notion of a criminal offense. There is no convenient name for such a theory, but it is easily characterized. The theory of pumishment that goes with the harm principle is a theory that views pumshment as justifiable msofar as it focuses on the avoidance of harm, rather than on the avoidance of immoral acts. ${ }^{171}$

As Moore points out, there are a number of criticisms of the harm principle a legal moralist might make. ${ }^{172}$ For example, he might question why the infliction of harm provides a good reason to limit liberty. What is it about harm-prevention that justifies governmental coercion? Moore suggests that most harm inflicted on others is morally wrong, and that this provides the real justification for interfering with harm-producing conduct. ${ }^{173}$ Thus, he would argue, harm is not in and of itself an adequate justification for restricting liberty. It appears to be so only insofar as harming a person normally wrongs him. We also sometimes punish "harmless wrongdoing," such as defamation of the dead or public nudity. Are we not right to punish such conduct on the grounds that it is morally

168. For a thorough exploration of the problems with legal moralism, see 1-4 JOEL FeINBERG, THE Moral Limits of the Criminal LaW (1984-88).

169. MilL, supra note 44 .

170. Id. at $10-11$.

171. One might suppose this describes a deterrence-based theory of pumshment, but this would be incorrect. Deterrence is a theory about the correct quantum of punishment, rather than a theory identifying which acts to punish and why. The point is confusing, since retributivism provides both an answer to the question of what to punish and an answer to the question of how much punishment is due. Other theories of punishment address these questions separately.

172. See MOORE, supra note 1 , at 753 .

173. See id. 
reprehensible? ${ }^{174}$ Finally, Moore points out that there are many instances of causing harm that are not punished, such as harming someone through economic competition. Does that not show that punishment cannot be directed towards the avoidance of harm? ${ }^{175}$

While these poimts are compelling, they are far from conclusive, and in light of the following responses, they are not generally thought to clinch the case against a harm-based theory of criminal prohibition. First, from the fact that many instances of harm-infliction involve inorally wrongful conduct, it does not follow that the noral wrongfulness of the conduct is the reason for punishing it. Indeed, Moore's argument seems to reverse the usual way we think of the relation between immorality and harm: We are normally inclined to think of conduct as morally wrongful because it is harmful, rather than the other way around. It thus seems more plausible to say that the reason we punish certain acts and the reason those acts are wrongful is the same, namely that the conduct inflicts harm. Second, it is not at all clear that the supposed cases of "harmless wrongdoing" are not predicated on the harm primciple after all. It is plausible that a person cannot be harmed after he is dead, but that does not mean that a law prohibiting defamation of the dead does not aim at harm-prevention. Such acts can be harmful to those who are alive, perhaps because it is disturbing to hear a loved one defamed, or because it creates insecurity to the living to know they might be defamed after death. Public nudity may not appear to inflict any identifiable harm, but it may inflict a more diffuse harm, for example, the erosion of social practices of respect for bodily integrity. ${ }^{176}$ Third, no one supposes that all harms are proper objects of punishment. Accordingly, we should not understand the harm principle as providing sufficient conditions for the justification of punishment. What the notion of harm supplies in this context is a threshold condition for justified punishment, the absence of which makes the nore political and pragmatic considerations that legislatures debate irrelevant to the permissibility of the proposed criminal offense.

What about accounting for mala prohibita crimes? Does the harmbased theory fare better than legal moralism? It is easier to justify prohibiting conduct for instrumental reasons on a harm-based account than it is on the coinparable legal inoralist account. For if the use of the criminal sanction is justifiable in order to avert harm, it does not much matter if the prohibited behavior is productive of some further harm or whether it is the behavior itself that is harmful. In either case, the required set of elements

174. See id.

175. See id.

176. Feinberg, who mounts a compelling defense of the harm principle, nevertheless concedes that such cases inust be addressed outside that principle. He accordingly suggests supplementing the harm principle with the "offense principle," which would justify prohibiting conduct that causes serious offense as well. See generally 2 FEINBERG, supra note 168. 
would stem from the nature and magnitude of the harm in terms of which the use of the criminal sanction is justified. Mala prohibita crimes thus appear to be easily accommodated on a substantive account of offense definition, as long as the principle of justification that theory supplies remains morally neutral.

Thus far this Article has suggested that a liberal order is committed to a background right to liberty that can be justifiably infringed only for the purpose of harm-avoidance. If this is correct, it is plausible to think that it also imposes a requirement on legislatures to draft criminal offenses im a way that contains a clear specification of the relevant harm. This is the function that the core elements are meant to serve: A criminal offense must be constituted by the basic elements necessary to identify the harm that justifies the punishment associated with that offense. A legislature can always add additional elements, over and above those minimally required to meet the burden of justification. But a criminal offense is underspecified when the harm the statute targets is insufficient to justify the degree of interference with liberty the statute imposes, taking imto account the other means available to a legislature for satisfyimg its purpose. And if the conduct the statute targets is not a harm at all, there is no offense defimition a legislature could select that would justify its prohibition.

When the requirement of justification is interpreted in light of the harm primciple, it provides a plausible way of understanding a number of the cases we considered im the previous Part. Vaguely worded statutes that fail to identify the harm towards which the criminal measure is directed are problematic because they will often be used to target nonharmful conduct by police and prosecutors. One cannot be sure from the terms of the statute alone that the restriction on liberty will be justified by the harmfulness of the conduct the statute prohibits. Moreover, we might say that a statute does not satisfy its burden of justification unless that justification is publicly available from the explicit terms of the prohibition. The vagueness cases thus help us to refine further the requirement of justification. That requirement deinands not only that the criminalized conduct produce some harm the legislature has a valid purpose to prevent, but also that the harm be sufficiently identifiable to inake the statute's justification apparent from the terms of the offense.

These themes also underlie the prohibition of status offenses and the mistake-of-law cases we considered: The identification of the prohibited conduct must leave potential defendants a way of avoiding the harm the law seeks to prevent, a condition that follows from the goal of harm avoidance. That opportumity is not available if the offense criminalizes a state of beimg imstead of behavior, or if it criminalizes wholly passive behavior or other behavior that the offender had no reason to know was harmful. Notice that this opportumity need not be available on a legal moralist's 
account, since there is no reason to think that a person cannot deserve punishment for being in a depraved moral state. It would also explain why it is not a defense that the defendant did not know his conduct was criminal, except in those cases of mala prohibita where the prohibition has received inadequate publication. It is a defense, however, if he did not know its nature and effects, a disparity the harm theory readily explains. If the conduct is harmful in and of itself, as is the case with mala in se crimes, the defendant is on notice of the possible illegality of his conduct. If the conduct is only instrumentally connected to some harmful state of affairs, the defendant cannot be expected to know that his conduct is illegal, and thus he must be placed on notice through publication.

In the privacy cases, the Court found that the balance between the liberty interest the criminal statute infringed and the harm the legislature sought to prohibit was not sufficient to meet the burden of justification. In some cases, such as Griswold, ${ }^{177}$ the imvasion of liberty may be particularly objectionable because the offense may not identify anything one could plausibly consider a harm in the first place, either in itself or instrumentally. It is not surprising, therefore, that the cases striking down statutes on privacy grounds mostly concern consensual conduct or conduct that does not affect the interests of persons other than the actor. ${ }^{178}$ The "harm" the statute seeks to prevent in such cases is minimal or nonexistent, and thus the Court often sees the infringement of liberty as unjustified.

There is interesting jurisprudential precedent for turning to a harm principle to develop a theory of justified criminalization. Bentham seems to have had something of the sort in mind when he insisted that laws, criminal offenses in particular, must be "complete."179 Bentham's idea of what makes a law complete is tied to the notion of harm. He writes that every law must be made "upon the consideration of some mischief" the legislature wanted to discourage. ${ }^{180}$ Whether a law is adequately premised on the prevention of a given harm is not a matter to be left entirely to legislative judgment, for Bentham offered the requireinent of completeness as a criterion for assessing legislation. He argued that a law is incomplete "in point of design" if the mischief the statute specifies "deviates from that whicl ... it is thought [the legislator] should and might have formed to

177. Griswold v. Connecticut, 381 U.S. 479 (1965).

178. The notable possible exceptions to this are the abortion cases. But the overwhelming majority of those inclined to treat abortiou as a matter for private choice also are inclincd to think that a fetus is not the bearer of separate interests of its own. Those, like Judith Thomson, who wish to argue for the permissibility of abortion even under the hypothesis that the fetus is a bearer of interests, however, need not reject the harm principle. They need only think that the harm inflictcd is not sufficiently great to warrant interference with the liberty right of the mother to choose. See Judith Jarvis Thomson, $A$ Defense of Abortion, 1 PHIL. \& PUB. AFF, 47, 61-62 (1971).

179. JeREMY Bentham, OF LAws in General 156-83 (H.L.A. Hart ed., 1970) (describing how complete law varies according to fullness of pattern).

180. Id. at 160 . 
himself."181 In this light, it should seem somewhat iromic that Bentham is ranked as among the most committed proponents of legal positivism. The charge is not altogether incorrect, given his adherence to a command theory of law. But he nevertheless allows for some important restrictions on the notion of "law" that eliminate some commands from counting as law, im particular, those that fail to identify discrete harms. Thus the application of the harm principle to the basic identification of criminal offenses this Article has proposed echoes Bentham in its suggestion that any harm or evil the legislature wishes to prohibit must satisfy certain internal conditions for its own "completion." A theory of offense definition is simply a way of requiring that legislative attempts to discourage harm identify the relevant harm in its totality if the interference with the liberty of subjects is to be constitutionally justifiable.

This Article will not make specific proposals for when a court should judge the harm principle satisfied and the burden of justification for an offense definition met. But it would nevertheless be useful to consider more concretely how a harm-based theory of offense definition would work in at least one fairly stark example. Once agam, the current Article is mostly concerned with suggesting a possible framework within which a constitutional theory of offense definition might be developed. But the plausibility of the framework will be enhanced by showing how such a theory might operate in the "easy" cases, namely the cases in which our intuitions are reasonably clear.

A typical definition of rape is sexual intercourse with another person "by force or threat of force against the will and without the consent of the other person." 182 Suppose a legislature is concerned about the difficulty of gaining convictions in rape cases due to problems of proof. It therefore decides to allow the prosecutor to establish a prima facie case on the basis of intercourse alone, shifting the burden to the defendant to disprove the charges by showing that he acted without force and with the consent of the other person. Would it be permissible for a legislature to structure its offense defimition this way? As we saw in Part I, Patterson was right to equate the restrictions on the prima facie case with the restrictions on the definition of the offense itself. The question, then, is whether it should be impermissible for a legislature to criminalize rape itself $\mathrm{m}$ this form. While the poimt is not entirely beyond argument, a legislature ought not to be able to forbid consensual intercourse between adults. We can put the point in general, jurisprudential terms by suggesting that sexual intercourse between consenting adults is not a harm or evil that could justify the use of the criminal sanction. Under the harm principle, a criminal offense whose purpose it is to prohibit immoral but nonharmful conduct is not justifiable

181. Id.

182. MD. CODE ANN. art. 27, §463(a)(1) (1957). 
as a valid infringement of liberty. A court could thus find that the proposed rape statute failed to meet its burden of justification.

But what about the Georgia anti-sodomy law the court upheld in Bowers v. Hardwick $?^{183}$ If the Court is predominantly concerned with harm, and the harm the Georgia legislature sought to avert by criminalizing sodomy was sufficient to justify the significant infringement of the liberty interest citizens have in sexual autonomy, arguably the inore serious harm of rape could justify vastly greater infringements on that same interest. Would the harm principle help to supply a theory of offense defmition in this case?

Bowers, however, is a rather stunning illustration of why a harmbased theory of justified criminalization is to be preferred to both positivism and legal moralism. Had the Court recognized a harm-based account of offense defimition as a legitimate way of protecting individual liberty it probably would have found the use of the criminal sanction in Bowers unjustified. At the very least, adopting a harm-based theory in the place of either a inorality-based theory (legal moralism) or no theory at all (positivisin) would focus debate about such statutes in the right place. The question would becoine whether forbidding consensual sodomy was sufficiently important to public welfare to justify the extensive infringeinent of liberty involved. At any rate, private "immorality" such as this might be presumed to be nonharmful. Any argument for its prohibition would require a deinonstration of its ill effects on others. While inuch would have to be filled in to articulate fully a theory of harm, our tradition generally assuines that nonimpaired adults are the best judges of their own interests, and thus the fact that conduct is consensual is usually sufficient to suggest its nonharmful nature.

Now return to the hypothetical rape statute we considered above. In this case, the harm or evil, namely forcing intercourse on an unconsenting participant, is more significant than intercourse between consenting adults. At least if we were to characterize the legislative purpose as discouraging forced intercourse, the aim of the statute would be quite a compelling one on a harm-based approach to justification. The question then would be whether the chosen ineasure was more liberty-infringing than necessary to prevent the harm in question, or whether there was a feasible, less libertyinfringing means the legislature might have chosen to accoinplish its purpose. Considered in this light, it seems reasonable to require that a prima facie defimition of rape contain either force or nonconsent as an element, since attempting to prevent rape by criminalizing ordinary intercourse is

183. 478 U.S. 186 (1986) (upholding state statute criminalizing consensual sodomy). The opposition to this case, however, suggests that it may be out of keeping with mainstreaun constitutional principles. See FARBER ET AL., supra note 41, at 548-51 (presenting different objections to decision). 
significantly more liberty-infringing than reasonably necessary to accomplish the only legitimate legislative purpose in this area. ${ }^{184}$

Matters becoine slightly more complicated where mala prohibita crimes are concerned, but not insurmountably so. The problem is often that either the measure adopted seems too remotely related to the harm for the prohibition to be justified, or the harm must be speciously characterized. For example, we would probably be tempted to identify every traffic regulation as a ineasure designed to increase automobile and pedestrian safety. But is this really sufficient to justify the minute requirements of the typical motor vehicle code? Surely a state could eliminate a large number of these measures without a significant loss in safety. On the other hand, we can characterize the end more narrowly, so that the measure will bear a more productive relationship to the state's purpose. The "no right on red" rule of many cities and some states may not be a required safety ineasure, simce many states do without it. And it does impose a significant burden on drivers in loss of time and increased driver frustration. If we characterize the end of such legislation as minimizing conflicts between drivers and pedestrians in dense urban areas, however, the selected means seems more sensibly related to the end. In this case, we would have to ask whether there was a significantly less invasive alternative the legislature could have adopted to accomplish the same purpose. Or consider the analysis one might make of legislation dictating which side of the road to drive on: While forbidding driving on the left is liberty-infringing, it is no more liberty infringing than the other available alternative for coordinating traffic, namely forbidding driving on the right. The third alternative, allowing drivers to choose for themselves, is admittedly less liberty-infringing, but it would not advance the legitimate legislative purpose of minimizing the number of accidents.

This Part has sought to present the outlines of a substantive theory of offense definition that is consistent with the dominant approach to liberty im our constitutional tradition. Such a theory seems necessary because the prevailing positivistic approach to the notion of an offense is out of keepmg with that tradition, and the other important alternative to positivism, legal moralism, seems to strain our intuitions in many important respects. Let us now return to the two constitutional doctrines with which we began,

184. Notice, however, that if we characterize the legislature's purpose more broadly, such as reducing the amount of intercourse, including unconsented-to intercourse, the purpose is arguably no longer legitimate. We can in this way fix an unnecessarily broad selection of means simply by changing our characterization of the end, and thus assume that the means is not irrationally or disproportionately related to the end. But in this case, we vastly expand the invasiveness of the end, and the measure would fail because of the illegitimacy of the state purpose. In general, a legislature's purpose becounes quickly rather bizarre when we start expanding the legislative purpose outwards to tighten the relation between means and end. And indeed the rational basis test is interpreted more plausibly if the end is characterized more narrowly and the real review pertains to the choice of means. 
in order to give a rough sense of how a substantive theory of offense definition would alter them.

\section{$\mathrm{V}$}

Towards a Substantive Approach to Burden of Proof and DOUBLE JEOPARDY

A substantive theory of offense definition would place limits on the freedom of legislatures to define offenses. The result would be limits on the ability of the legislatures to engage in burden-shifting, as well as limits on their ability to authorize inultiple punishments for a single offense. In the burden-of-proof context, the core elements for each offense would establish the elements the legislature could not permissibly convert to affirmative defenses, given that this would remove them from the prima facie case. ${ }^{185}$ By contrast, a legislature could shift the burden with respect to nonmandatory elements of an offense, that is, elements that lie outside the core. One way of understanding this is to think of the nonmandatory elements of an offense as extra, that is, nonmandatory protection for liberty under the Due Process Clause. If, however, a legislature does choose to mclude nonmandatory elements in its offense definition, Winship will apply to those elements. For the presence of an element in an offense definition places citizens on notice that the state will have to make out certain facts in order to establish a prima facie case of guilt for that offense. By including elements in an offense definition that exceed the constitutionally required minimum, a state establishes an expectation that individuals will be free from the reaches of the criminal law if those elements are not satisfied, and this expectation creates liberty rights that courts may not obviate.

Understanding the prosecution's burden of proof in terms of mandatory elements of an offense would make good sense of Winship as a constitutional guarantee. The decision would stand for the proposition that the state must bear the burden of proving that minimuni set of elements necessary to vindicate the liberty interests of individuals under the Constitution. We can then understand the presumption of innocence as a constitutional guarantee with a significance and a content of its own. That doctrine would require, for example, that a man be presumed innocent of rape until a prosecutor had proven beyond a reasonable doubt that the

185. It at least requires the specification of such a set for any offense to which constitutional limitations on burdens of proof and related matters apply. As Larry Alexander has explained this position:

For the substantivists, there are federally defined core elements of each crime that cannot be eliminated, functionally as well as formally, or made into defenses, the burden of which is on the defendant. A federal law of substantive crimes, developed under the Due Process Clause, or the Eighth Amendment, is the substantivists' Winship-preserving alternative to Mullaney/Patterson.

Alexander, supra note 39, at 209-10. 
victim was nonconsenting. The legislature could neither draft its rape provision in such a way that excluded this element, nor shift the burden to the defendant to disprove it, since either scheme would eliminate the element from the prima facie case.

Defenders of Patterson-type positivism imight object that criminalizing intercourse without including an element like nonconsent falls outside the limits of constitutionality to which the Patterson majority referred. Perhaps the Patterson majority would have been prepared to regard shifting the burden of proof with respect to nonconsent as a violation of due process. But if so, the proponent of Patterson-type thinking must confront the following question: What is the difference between shifting the burden on nonconsent in rape and shifting the burden on extreme emotional disturbance in murder? It is not a sufficient response to say that the Due Process Clause ensures that states observe only the most minimal procedural safeguards. For the power to review a provision shiftimg the burden to a rape defendant to prove consent is presumably no greater than the power to review a provision shifting the burden on extreme emotional disturbance. Someone who took this line, then, would need to provide an argunient for why a legislature is obligated to include an element like nonconsent in rape and not obligated to include an element like lack of extreme emotional disturbance in murder. Furthermore, any such argument would by necessity be substantive; no formalistic reasoning will explain it. We might, then, summarize the difficulty with positivism about the notion of an offense as follows: If the positivistic approach is mcompatible with recognizing limits on the power of legislatures to defme the elements of an offense, it is inconsistent with other established principles of our constitutional jurisprudence-in particular, principles having to do with the protection of individual liberty. If, on the other hand, it is compatible with recognizing limits, it must also be compatible with a substantive theory of offense definition. Either way, there is reason to reject Patterson's positivism about the notion of an offense.

Unfortunately, most problenıs of offense definition are murkier than that of rape and nonconsent. Consider, for example, the relation between self-defense and homicide. Should we think of the absence of self-defense as an implicit element of all homicide offenses? Or is the absence of selfdefense a noninandatory element, thus allowing a legislature to shift the burden to the defendant? The question boils down to whether overcoming the presuniption agamst the prohibition on intentional killing depends on exenıtimg those who act in self-defense from the scope of the prohibition. And this, in turn, depends on the harm the prohibition is meant to address. Here we have fewer clear intuitions to guide us than we had in the case of rape and nonconsent. One feature of this example, however, may help. Notice that the norms that justify the prohibition on intentional killing 
apply equally to killing in self-defense. That is, the relevant harm is ending the life of another human being. And this justification remains applicable even if we do not exempt killing in self-defense from the scope of the norm. For killing one's attacker inflicts this harm on him, even if it does so justifiably. Compare this with the example of rape: If we eliminate the element of nonconsent from the scope of the prohibition, the conduct prohibited by the offense defmition itself is not the harmful conduct whose prohibition justifies the interference with liberty. Here the element of nonconsent is essential to identify the harm that justifies the decision to criminalize. Thus where killing and self-defense are concerned, we have two separate norins and two separate principles of justification: the norm that justifies the prohibition on killing and the norn that permits killing in selfdefense. The latter norm does not supplement the former; it overrides it. That is, the prohibition on homicide reflects the law's commitment to the protection of human life and the prevention of harm. Self-defense, by contrast, reflects a inoral entitleinent to repel wrongful violence against one's person. The latter stems from a different aspect of our moral and political philosophy than does the prohibition on homicide. And if this is correct, it would not be necessary to include the absence of self-defense in a murder statute in order to identify the harm the crime of murder prohibits. It would follow that the absence of self-defense is not a constitutionally required part of the offense definition for inurder, manslaughter, or any other homicide offense, and thus that legislatures could perimissibly place the burden on defendants to prove it.

We can draw soine general conclusions from the foregoing examples. The need to justify the iniposition of the criminal sanction suggests that we should treat a defense provision as part of the offense it qualifies when the prohibition cannot meet the requirement of justification without it. By contrast, when the offense provision is "complete" in the absence of the exonerating condition, the latter provision will not lie within the core of required elements and so may be treated as an affirmative defense. Our discussion of rape and murder shows that an exonerating condition is likely to be an implicit part of an offense definition and required for the latter's completion, if the principle that justifies the condition is the same as that which justifies the prohibition itself. That is, where the defense provision and the offense definition are both justified by the same principle or norn, the absence of the defense provision will probably be required to coinplete the norn the offense expresses. By contrast, an exonerating condition is likely to be external to the offense definition if the justification for the 
condition is different from that which justifies the rule of prohibition. In the latter case, the condition may be treated as an affirmative defense. ${ }^{186}$

Before turning to the problem of double jeopardy, let us digress briefly to address a general question about the constitutional core for offenses. Is the mens rea requirement for an offense part of the constitutionally required offense definition, or should only actus reus elements be included in the core? To answer this question, we will first require a distinction between the notion of core elements and a close cousin of that idea the criminal law already contains, namely the idea of a "material" element. The Model Penal Code defines "material element of an offense" as an element that, among other things, is not unconnected with "the harm or evil ... sought to be prevented by the law defining the offense."187 While both material and core elements are "connected" with the harm or evil the offense seeks to prohibit, the core elements are those material elements that are required for the offense defimition to meet its burden of justification. We should accordingly think of the test for "core" elements as more restrictive than the test for "materiality." A legislature could include a constitutionally extraneous element in its offense definition that would still be "material." 188 Most proponents of a substantive approach to offense definition urge the substantive stance precisely because they want to be able to insist on the inclusion of mens rea as a constitutional requirement. ${ }^{189}$ Their claim is most often that punishing in the absence of a mental state is unconstitutional because it inflicts the suffering and stigma of criminal conviction on a person who is not morally blameworthy. ${ }^{190}$ Some accordingly propose a minimum mental state requirement for all offenses, such as negligence or recklessness. ${ }^{191}$ It inay seem strange, then, that this Article has argued for a constitutionally required set of offense elements without including mental state elements in the set. But the ornission of inental state elements is defensible on a harm-based theory of offense definition, and indeed it may be required. First, unlike the case of legal moralisin, a harm

186. For a more detailed discussion of this point, see Claire Finkelstein, When the Rule Swallows the Exception, in Rules and Reasons: Essays in Honor of Frederick Schauer (Linda Meyer ed., 1999).

187. Model Penal Code $\S 1.13(10)$.

188. The comparison with the problem of materiality may help to allay a possible objection to the idea of a constitutionally required core-that the idea is so vague and indeterminate that courts will never be able to develop a consistent set of standards for identifying its constituents. But what the comparison with materiality shows is that judges presiding over criminal cases are routinely required to make determinations that are every bit as fuzzy and imprecise. There is no reason to suppose it would be appreciably more difficult to specify the core elements of an offense than it currently is to specify which elements of an offense are material.

189. See Packer, supra note 39, at 152.

190. See id.

191. See id. This is ultimately the position the Model Penal Code recommended, restricting the use of strict liability to de minimis infractions better thought of as violations than crimes. See MODEL PENAL CODE \$§ 2.02(1) \& 2.05(1)(a). 
theory does not require that the offender is morally blameworthy for punishing him to be justified. The proposals for constitutionalizing mens rea, by contrast, suggest a commitment to a moralized view of the criminal law. Second, the characterization of a harm or evil does not normally require a specification of the mental state with which that harm is inflicted. The object of a prohibition is some type of undesirable conduct, such as killing or taking the property of another, rather than conduct engaged in with a mental state of a certain sort. ${ }^{122}$ The mental state is not itself part of what is prohibited. This is not to say that there should be no constitutional restrictions on the use of strict liability in the criminal law, but just that any such restrictions must be based on constitutional values other than those contained in the due process liberty entitlement. ${ }^{193}$

If mental state elements are not part of the constitutionally required core, it follows that a legislature could constitutionally place the burden on a defendant to prove any mens rea-negating defense as well. ${ }^{194}$ The defense of mistake, for example, can normally be derived from the mental state element of an offense definition. If the crime of theft is defined as "tak[ing] or exercis[ing] unlawful control over ... movable property of another with purpose to deprive him thereof, ${ }^{, 195}$ a person who took movable property under the mistaken belief that it was his own would not satisfy the offense definition, since his mistake would negative the mens rea required for theft. ${ }^{196}$ Defenses like mistake are better thought of as an implicit part of the offense definition than as affirmative defenses when the criminal offense does contain a mens rea requirement. Thus, if the scienter requirement in theft were constitutionally required, it would be constitutionally mipermissible for a legislature to shift the burden of proof with respect to the defense of mistake, since that would be tantamount to making the absence of culpability a defense rather than its presence a requirement. If, however, a scienter requirement is not part of the core, as suggested, then it

192. See Moore, supra note 166 , at 3 .

193. Recently Alan Michaels has approached the constitutionality of strict liability in a fashion similar to the one taken here towards other elements of an offense. He argues that there is no uniform answer to the question of the permissibility of strict liability. Instead, he suggests that the legislature may impose strict liability with respect to a given element if the conduct the statute addresses could be constitutionally criminalized without that element. See Michaels, supra note 6, at 833. Michaels' approach to the problem of strict liability shares with the present Article the suggestion that certain elements of an offense may be constitutionally required while others may be supcrfluous. It is with respect to the latter that a legislature may impose strict liability, according to Michaels, and that it may shift the burden of proof to the defendant, according to the argument provided here. Michaels' article addresses strict liability only. On the present account, however, not only does the thcory of offense definition apply to other kinds of elements, but it ought not apply to mental states at all.

194. This is the case assuming, once again, that mens rea is not constitutionally required for other reasons.

195. Model Penal Code $\$ 223.2(1)$.

196. See id. $\$ 2.04(1)(a)$. 
would be permissible for the legislature to shift the burden on the defense of mistake.

Let us now turn to the ban on multiple punishment for the "same offense" under the Double Jeopardy Clause. On a substantive theory of offense definition, the central question of double jeopardy law would have a nonarbitrary answer. The question of when two offenses are the "same" and when different would once again be approached by comparing the core elements of each. Suppose, for example, the offense of murder contained the required elements of causation and the death of another human being. Any other elements a legislature might wish to include would be constitutionally "optional," such as making the statute applicable to fetuses as well. ${ }^{197}$ Murder and manslaughter would thus have the same constitutionally required core, since the same two elements that made up the core of murder would make up the core of manslaughter as well. We should expect this result, given that we have excluded mental state elements from the core, since the essential difference between murder and manslaughter is mens rea. The result makes sense and tracks current law. The legislature should not be allowed to punish more than once for murder and manslaughter when these charges arise from a smgle killing, since both prohibitions express the same background norm. Thus a court can determine whether two offenses are the saine or different by asking whether the two offenses have the saine or different background justifications. In the case of offenses and defenses, we saw that a defense should be thought "affirmative" when it steins from a different background justification from the justification that applies to the offense definition. The same logic is at work here: Two offenses are the same if they stem from a single background justification and different if they stem fronı two different justifications.

Brimging a substantive approach to offense definition to bear on the doctrine of double jeopardy preserves the character of the doctrine as a constitutional guarantee. For a state could not obviate the ban on multiple punishment simply by tacking on a different element to each of two offenses with a common core. It could not, for example, authorize multiple punishment for two offenses that are the "same" for double jeopardy purposes by including the term "unlawfully" in a murder prohibition and including the term "fetus" in the manslaughter provision. Since neither element would be part of the mandatory core, their inclusion would not serve to make them different offenses for double jeopardy purposes. Nor could the legislature simply announce its intention to punish the same

197. The term "human being" in a murder statute is usually not taken to include fetuses. See Keeler v. Superior Court, 470 P.2d 617 (1970) (holding murder statute inapplicable to killing of fetus). This apphication of a statute must therefore be provided for explicitly. 
offense twice, as condoned by Missouri v. Hunter. ${ }^{198}$ Any statute authorizing such a punishment scheme would be unconstitutional, and courts would be under an obligation to interpret ambiguous statutes so as to avoid this result or to strike down the statute if this proved impossible.

How, more specifically, would the above structure solve the two doctrinal questions about double jeopardy we have considered? Once again, this Part does not purport to offer a revised theory of double jeopardy, but rather simply to indicate how a substantive approach to the notion of an offense would affect the constitutional guarantee. A complete theory must await the articulation of specific restrictions on the notion of an offense under the Due Process Clause. Nevertheless, we can trace the domain in which a revised theory of double jeopardy would operate. First, let us turn to the question of cumulative punishment for an offense and one of its lesser-included offenses, and consider the difficult question of whether it would be permissible for a legislature to authorize cumulative punishment for felony murder and for the predicate felony used to prove it. If felony murder is constitutionally permissible, it must be because the constitutionally required core for murder does not include a mental state eleinent, as we have supposed. The core set of elements for any predicate felony, like rape or armed robbery, will then be substantially different from the core set of elements for felony murder. Both rape and murder express independent norms of prohibition, and each offense has its own background justification. The two are related in this case, or so the argument might go, only by legislative fiat. The legislature has chosen to include a nonmandatory mental state requirement in the definition of inurder, and it allows that element to be satisfied by the mental state for the predicate felony. But if it need not, strictly speaking, have done so, then we are entitled to think of these as two separate offenses expressing two quite different norms. On a substantive approach to offense definition, then, it seems plausible to allow for cumulative punishment for each offense.

By contrast, a substantive approach would probably not authorize cumulative punishment for the two offenses involved in Hunter, namely armed criminal action and its underlying felony. For arguably the prohibition on possessing a weapon does not have its own independent background justification, as shown by the fact that weapons possession is not illegal as such. Here a potentially legal activity is rendered illegal because another felony is committed in conjunction with it. This suggests that there are not two separate norms of prohibition, but only one. Punishment should therefore run concurrently rather than cumulatively.

While the overwhelming tendency of the cases on double jeopardy lies in the positivistic direction, there is some legal support for the substantive approach. The support, however, derives almost entirely from the

198. 459 U.S. 359 (1983). 
successive prosecution cases, where the Court has at times been tempted to develop doctrines that would preempt legislative manipulation. Ex Parte Nielson, ${ }^{199}$ for example, involved a man who had been living with two wives, who was tried first for unlawful cohabitation and later for adultery. The second prosecution did not technically violate the "elements" test, since cohabitation required living together but did not require sexual relations, while adultery required unlawful sexual relations but did not require cohabitation. Nevertheless, the Court found that the two offenses were essentially the sanie, in light of the fact that both offenses were meant to prohibit the same harm or evil. What the Nielson Court recognized is that a legislature should fashion a single crime to address a smgle harm or evil. ${ }^{200}$ If the legislature criminalizes the same harm twice, albeit in slightly different terms, this should not be sufficient to subject a defendant to two sentences for what is in essence the same crime. Of course the legislature may have wanted alternative formulations of the same offense, since the ban on double jeopardy does not bar a prosecutor from charging a defendant with both offenses, and it need not even prohibit conviction for both, as long as the state does not punish each offense separately. Under these circumstances, the constitutional guarantee will require a state to choose, by insisting that it inflict only a simgle pumishment for the perpetration of a single harm or evil.

Notice, too, that a substantive approach to the notion of an offense has the advantage of allowing us to dispense with the asymmetry between the two branches of double jeopardy law, simce the concept of an offense will provide the necessary demarcation for both. Thus, not only should a court compare the core elements of two offenses the legislature has drafted to determine whether sentences for them can run cumulatively or must run concurrently, it should apply the same test to determine whether it is permissible to bring a second prosecution for an offense arising out of the same transaction as an earlier prosecution. If, for example, the state tries a defendant for manslaughter, whether he is acquitted or convicted at the first trial, he cannot subsequently be tried for murder. The reverse would also clearly be true: A conviction or acquittal for murder would bar a subsequent prosecution for manslaughter. If, however, a defendant shoots someone in the course of committing a robbery, he could first be tried for armed robbery and later for murder arising from the gunshot wound.

This would solve the Grady/Dixon problem, where the defendant is convicted for a mimor infraction arising out of a transaction in which he exposed another to a risk of death, and the victim later dies. Although the Court has adopted a variety of techmiques to deal with this situation, ${ }^{201}$ the

199. 131 U.S. 176 (1889).

200. See id. at 186-88.

201. See supra text accompanying notes $92-96$ and sources cited therein. 
resulting doctrine is convoluted and ad hoc. Without entering into this labyrinthine area of law in detail, the substantive approach holds out the proimse of a simple and elegant solution. The state may impose successive prosecutions on a person who has committed two or more distinct offenses, identified according to the substantive approach to offense definition, and otherwise it must try all charges in a single proceeding. Thus the defendant in Grady could be tried for manslaughter in a separate proceeding after he had pled guilty to drunk driving, since the core elements for the traffic offense and for manslaughter are not the same (nor is one contained within the other). On the other hand, once the state prosecutes someone for attempted murder, it cannot bring a second prosecution for murder if the victim of the attempt subsequently dies. While this may seem a regrettable result, it does not seem unfair to require the prosecution to choose between a speedy conviction for attempted murder and a inore time-consuming conviction for murder, all the while retaining the possibility of prosecuting atteinpted murder if no death results within the required time.

It might be argued that this approach is overly harsh by comparison with the current law on successive prosecutions, for it would not at present be possible for the state to try a defendant more than once for different offenses arising out of the same transaction in many circumstances, such as when the facts needed to prove the offense at the second trial formed the basis for the prosecution's case in the first. ${ }^{202}$ This rule is thought necessary to protect defendants against the harassment of multiple prosecutions for the same underlying events. But there is no reason to suppose that the ban on double jeopardy was ever meant to be a rule about harassment. Indeed, as was pointed out in the debates surrounding the drafting of the Double Jeopardy Clause, a legislature might authorize multiple prosecutions as a protection for those accused of crimes, rather than as an unwanted source of harassment. ${ }^{203}$ The standard refrain about harassinent and the value of

202. See Ashe v. Swenson, 397 U.S. 436 (1970).

203. See Remarks of Mr. Benson discussing proposed draft of constitutional amendment in First Congress (August 17, 1789), in The Bill of Rights: The Drafts, DEbates, Sources and ORigins 310 (Neil H. Cogan ed., 1997). This point is easy to see by imagining the following scenario. Suppose the legislature wants to remedy what it thinks is a problem with excessively proconviction sentiment among juries, and the resulting long sentences and possibly unfair convictions they seem to engender. It therefore passes a measure requiring a new trial for each year of incarceration a defendant faced as a result of conviction for a given offense. To sentence an offender to 20 years, for exanple, the prosecution would be required to bring 20 differcnt trials and impanel 20 different juries, one for each year. Suppose, further, that a defendant could always waive this extra protection, and elect to have all 20 years adjudicated in a single trial. It would seem odd to suppose that the ban on double jeopardy would forbid a legislature from passing such a measure. True, it might be unnecessarily wasteful, and it would arguably work a serious unfairness on the state. But there does not seem to be a violation of the rights of a defendant in allowing such a scheme, since the defendant could elect the procedure that he saw as most advantageous. Thus if we are to preserve the identity of double jeopardy as a constitutional guarantee, and also preserve the notion of a constitutional guarantee for individuals as a right they 
closure in the literature and opinions on successive prosecution ${ }^{204}$ is reminiscent of the proceduralist interpretations we saw in the burden-of-proof context. ${ }^{205}$ Where there appears to be no intrinsic justification for a certain constitutional guarantee, commentators cast about for some additional value that is "external" to the constitutional doctrine, in an effort to vindicate the doctrine by seeing it as instrumentally related to that value. These contortions, however, only become attractive when needed to breathe life into a constitutional guarantee that has been deprived of its otherwise natural content. Against the background of a substantive theory of offense definition, we can take both the presumption of innocence and the ban on double jeopardy as constitutional values in their own right. There is no need to cast about for some further constitutional value these doctrines are meant to serve.

Let us now consider whether a substantive theory of offense defimition can shed light on the second problem we considered in the double jeopardy context, nannely the unit-of-prosecution problem. This is a fiercely difficult problem, one that has troubled commentators and practitioners alike for many years. The suggested franework for a theory of offense definition will not be able to solve the difficulty, but hopefully a fully articulated account of the notion of an offense would. For while the legislature will ordinarily have fairly broad discretion to determine the relevant unit of prosecution, the requirement of justification would place boundaries on the units of conduct to which criminal offenses apply. Permanently removing a person's property witliout his consent, for exainple, is a harm that theft statutes seek to discourage. But it is not appreciably worse to steal property and retain it for fifteen mimutes than to retain it for ten. For this reason, a statutory scheme that treated every ten minute interval as a separate offense might fail to meet its burden of justification, since it would make the potential punishment for a single wrongful act of theft arbitrary and arguably inore invasive of liberty than reasonably necessary.

This kind of restriction on criminal legislation, however, may seem pointless. What contribution to liberty does restricting legislative decisions about the unit of prosecution serve? The restriction itself, however, need not itself promote liberty. It is rather that restrictions on the notion of an offense follow from a right to liberty. Then against the background of a substantive notion of an offense, it is possible to give noninstrumental mearning to the ban on double jeopardy. Instead of asking what purpose that doctrine serves, we take the constitutional provision as sufficient grounds for the doctrine, and then proceed to interpret the provision in

possess against their governments, we ought not to think of the avoidance of harassment as the main value the ban on successive prosecutions is designed to protect.

204. See generally Drubel \& Westen, supra note 78.

205. See supra text accompanying notes 64-73. 
light of the notion of an offense on which it rests. We need not ask, for example, about the purpose of the right to free speech before we conclude that such a right exists. The textual provision is sufficient grounds for taking the right to be fundamental.

A second answer, however, can also be given that helps to situate individuation restrictions in the tradition of individual liberty on which we have been drawing. On a substantive approach, the elements of an offense should bear some internal relation to the underlying value the offense is meant to protect. If the legislature wishes to protect its citizens against the harm wrought by insecurity in property rights over movable objects, the individuation of offenses should track our ordinary divisions among those objects. If, for example, the legislature wishes to guard against theft of barn animals, it ought to assign one count of theft for each animal reinoved from its owner. This is particularly important for traditional malum in se crimes. It is argnably the harm-based nature of the prohibition that makes it fair to assume citizens are on notice of the illegality of their conduct. Thus a statute criminalizing theft of a single cow as fifty counts of theft-one corresponding to each cut of beef the cow could produce-could easily fail the notice requirement. Notice is of course its own doctrine, and thus it might seein that any concern with notice could be addressed directly through the Due Process Clause. But that doctrine traditionally requires no publication for mala in se crimes. Actual notice, therefore, is not required. Arguably, the doctrine of presuinptive notice is only acceptable because the crimes to which it applies track natural offense divisions. And thus notice and the substantive notion of an offense point in the same direction.

The requirement that legislatures observe "natural" divisions, however, is less stringent for inala prohibita crimes. For here there are few intuitions with which statutory publicity inust compete. Thus a regulation dividing a cow up in a counter-intuitive way is less damaging if it pertains to a labeling requirement for beef rather than theft. And this is why pubhcizing a statute may sometimes cure a defect in the individuation of offenses for mala prohibita crimes, but why such defects are harder to cure for crimes that are inala in se.

Finally, even if notice were not problematic, allocating a separate punishment for each cut of beef would probably leave the punishment for stealing an entire cow unjustified, given the significant deprivation of liberty it would involve. For not only would a defendant be subject to separate but cumulative penalties for a single transaction, but he could be tried fifty times for what is essentially the same harm. The power a legislature could give to prosecutors for any otherwise minor offense would be extensive. And given the general absence of proportionality constraimts outside the death penalty area, the punishment for some conduct could easily becoine extremely harsh. Indeed, the problem would not even be entirely 
alleviated by resuscitating the jurisprudence of proportionality. For that doctrine would place an upper bound on permissible punishment for each instance of a given offense. It would not limit the total number of instances of an offense for which a defendant could be prosecuted arising out of a single transaction. In this sense, the doctrine of double jeopardy, on a substantive interpretation, seems a necessary concomitant of the Eighth Amendment ban on cruel and unusual punishment.

This Part has offered only the most general indication of how a substantive theory of offense definition would revise the presumption of innocence and the ban on double jeopardy. It has tried to show that a siniple and natural interpretation of each doctrine would ennerge if combined with a substantive theory of offense definition. While current criminal law jurisprudence is committed to seeing the notion of an offense as a legislative concept, to iniport this perspective into constitutional provisions that depend on the notion of an offense is both distorting and anachronistic. The view of criminal offenses as creatures of legislative fiat is a relatively recent one. A constitution that built its criminal guarantees around a view of crime as created law would probably have been structured quite differently from our current Bill of Rights.

\section{VI \\ CoNCLUSION}

The positivist understanding of the notion of an offense appears to be the terra firma on which the various debates about constitutional criminal law take place. This is a curious feature of contemporary criminal law jurisprudence, for such an approach seeins neither required by our criminal law concepts nor internally consistent with our constitutional tradition. Indeed, as this Article has argued, it stands in some conflict with the aspect of that tradition that has to do with individual liberty, on at least one prevalent and compelling understanding of that notion. It should also be stressed that the positivist stance is not a necessary concoinitant of a nonmoralized view of the notion of an offense. It is an unfortunate feature of the niodern conception of law that the alternative to law as the arbitrary exercise of sovereignty is the highly moralized legacy of natural law theories. One of the advantages of securing rights through a constitutional structure is that "created" law can be limited by and interpreted in light of the more general principles of our political philosophy that constitutional structure expresses. In this sense, our most basic constitutional concepts are neither wholly "created" on the one hand nor entirely "discovered" on the other.

The alternative to positivism about the notion of an offense this Article has explored treats the notion of an offense as the product of a theory of justifiable interference with liberty. That theory is based on an 
argument about the role of harm in justifying infringements of liberty. A number of important questions, however, remain unanswered, and whether a substantive theory of offense definition is ultimately defensible will depend on the plausibility of the answers we give them. First, this Article has not sought to provide a complete theory of punishment. What the harm-based theory of justified liberty-infringement suggests is only that criminal prohibitions track harm that justifies the particular infringement of liberty the statute authorizes. A harm-based theory of punishment would require extensive further argument to be convincing, and in particular to be convincing as an articulation of a constitutional theory of justified libertyinfringement.

Second, this Article has not attempted to provide any account of harm itself. What exactly is a harm and what kinds of harms are of sufficient gravity to justify infringing the liberty of citizens? A more precise specification of the proper objects of criminal prohibitions would ultimately require a more thorough account of the notion of harm. The absence of a theory of harm, however, is not a lacuna of a theory of offense definition. For the concept of harm need not itself be constitutionally specified. And unlike liberty and property, the notion of harm need not be legislatively defined if it is not constitutionally supplied. There are certain concepts the law must borrow from ordinary practices. But a theory of harm is nonetheless necessary if legislatures and judges are to apply a harm principle to judge actual legislation, and thus the notion of harm will have to be a welldefmed one.

Finally, the notion of liberty requires much greater exploration. For the limits on the notion of an offense will be the mirror image of the shape of the right to liberty citizens possess. If, as many appear to think, there is no general background protection for liberty per se, limits on offense definition will remain ad hoc and difficult to justify. Alternatively, they might disappear altogether. 